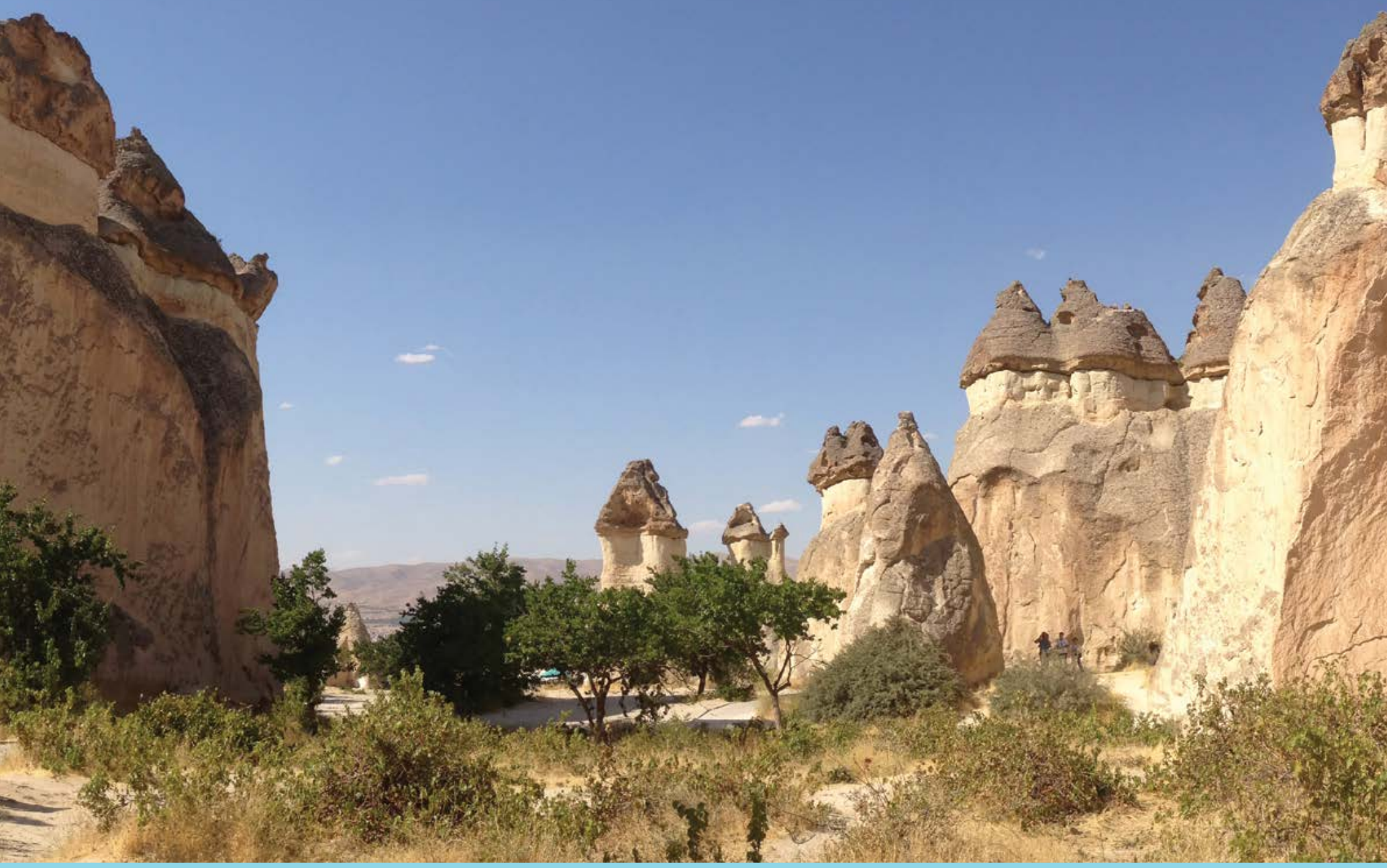

CHAPTER 22

MANAGING CULTURAL USES AND FEATURES

Principal authors:

Fausto Sarmiento and Edwin Bernbaum

\section{Supporting authors:}

Jessica Brown, Jane Lennon and Sue Feary

\section{CONTENTS}

- Introduction

- Managing for contemporary cultural practices

- Managing cultural use with integrative approaches

- Managing for cultural spiritual values

- Managing cultural use of sacred sites

- Managing cultural features (tangible cultural heritage)

- Conclusion

- References

IUCN 3 WCPA 


\section{PRINCIPAL AUTHORS}

FAUSTO SARMIENTO is the Professor of Geography and Director of the Neotropical Montology Collaboratory at the University of Georgia, Athens, USA.

EDWIN BERNBAUM is Co-Chair of the International Union for Conservation of Nature (IUCN) Specialist Group on Cultural and Spiritual Values of Protected Areas and Senior Fellow at The Mountain Institute, Berkeley, California.

\section{SUPPORTING AUTHORS}

JESSICA BROWN is Executive Director of the New England Biolabs Foundation, and chairs the IUCN World Commission on Protected Areas (WCPA) Specialist Group on Protected Landscapes/Seascapes.

JANE LENNON is a historical geographer with more than 30 years' experience in natural and cultural heritage management, and is Honorary Professor in Landscape Heritage at the University of Melbourne, Australia.

SUE FEARY is an archaeologist and national park manager, with 25 years' experience in management of natural and cultural heritage and consulting with Aboriginal Australians.

\section{ACKNOWLEDGMENTS}

The authors would like to thank Josep-María Mallarach, Thymio Papayannis, Mark Infield, Arthur Mugisha, Shalini Dhyani and Deepak Dhyani for their case study contributions. Also, thanks to Alejandro Argumedo for the example of the Potato Park and to Randall Borman for the example of the Cofán Bermejo Ecological Reserve. Thanks go to Sharon Sullivan for a critical and very useful review of an early draft of the chapter.

\section{CITATION}

Sarmiento, F., Bernbaum, E., Brown, J., Lennon, J. and Feary, S. (2015) 'Managing cultural features and uses', in G. L. Worboys, M. Lockwood, A. Kothari, S. Feary and I. Pulsford (eds) Protected Area Governance and Management, pp. 685-714, ANU Press, Canberra.

\section{TITLE PAGE PHOTO}

Göreme National Park and the Rock Sites of Cappadocia, World Heritage Property, Turkey: the soft volcanic rocks have been eroded into spectacular pillars and minaret-like forms. It has been settled since Roman times and includes many rock-hewn sanctuaries Source: Ingrid Iversen 


\section{Introduction}

In this chapter, we explore the administration of cultural uses and the management of cultural features within protected areas. Our review emphasises some of the emerging shifts in thinking about cultural heritage, such as the integration of the protection of natural and cultural objectives, emerging conservation paradigms of cultural landscapes and biocultural diversity, and the growing attention being paid to the role of indigenous peoples and local communities in stewardship of protected areas. We also discuss principles and practices applicable to management of cultural features, including built heritage and places of religious significance.

Humans use the modern protected area system in many different ways, and in one sense, all human use is cultural. Uses can be prompted by the protected area status itself, which may offer, for example, unique recreation, educational or commercial tourism opportunities. Uses can also include religious practices or activities that shaped the environment long before the protected area came into being.

Recognising that biological and cultural diversity have coevolved and that conservation of biological diversity is often linked to the traditional lifestyles of indigenous and local communities brought about important changes in protected area thinking. Use of terms such as 'biocultural diversity' and 'biocultural heritage' reflect a changing paradigm that envisages human activity as part of the ecosystem process. Cultural use encompasses all human activity within a protected area, and managing that use has many different dimensions. It can include law enforcement against illegal activities, through to devolution of power to local communities to manage their resource use within a protected area. In this chapter, we focus on integrated approaches for managing contemporary use of protected areas by indigenous and local communities. We also present information on the complexities of managing the use of sacred sites by different religious groups and the public.

As well as intangible heritage, most protected areas contain tangible evidence of past human use that can span many thousands of years. It may be valuable, rare or irreplaceable. These cultural features can include ancient archaeological sites, cultural landscapes, buildings, monuments or pathways, or complexes of features. Many continue to have great meaning to the people with whom they are associated. Managing these cultural features is therefore not only about managing or preserving historic evidence (sometimes termed 'fabric'); equally it can be about engaging with a local community, family

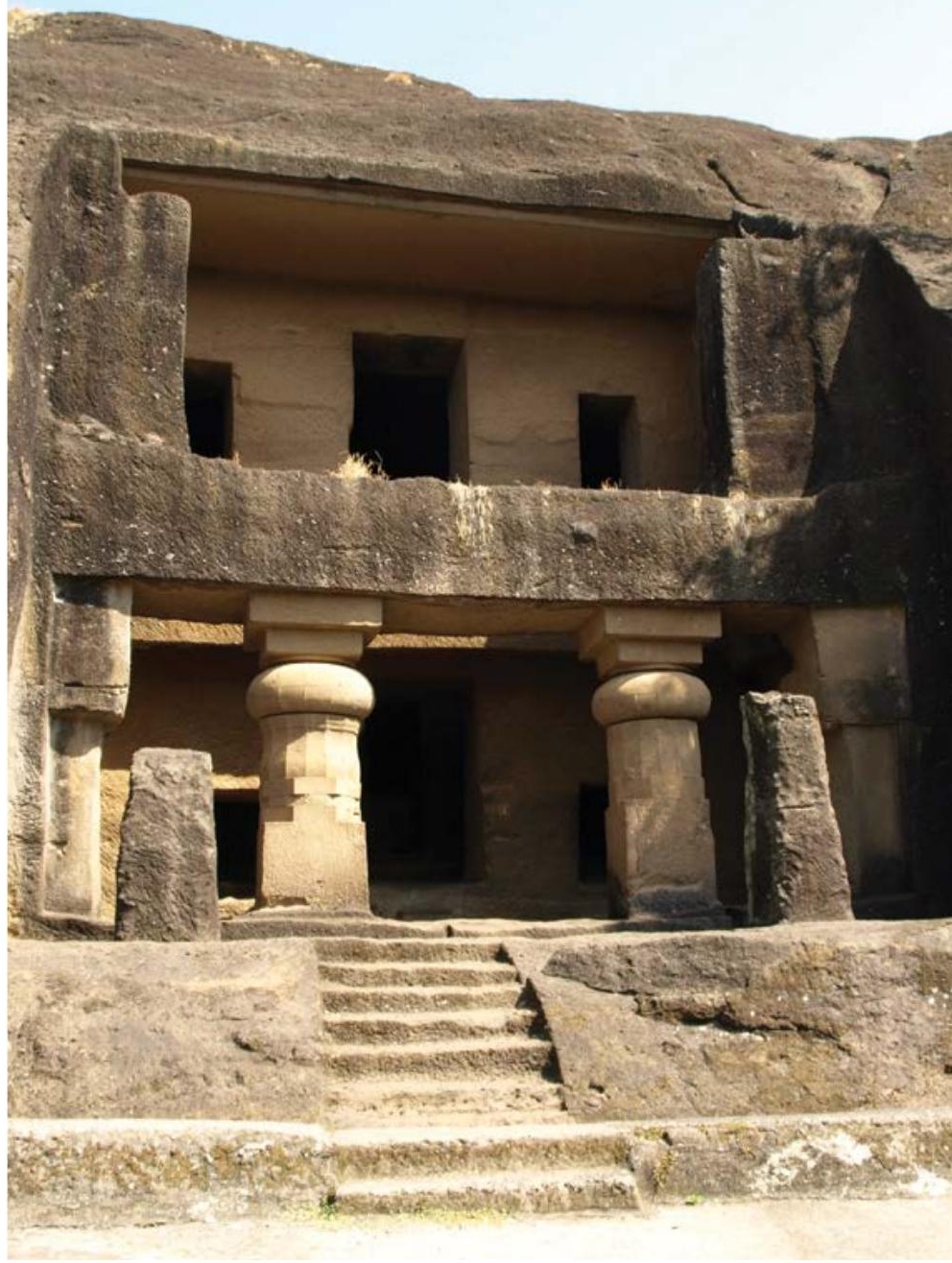

Buddhist caves, Kanheri, Sanjay Gandhi National Park, India: the carved caves in volcanic breccia illustrate Buddhist influence on the art and culture of India

Source: Graeme L. Worboys

or indigenous group whose ancestors constructed the building or created the cultural landscape. We apply the principles and practices of cultural heritage management to the conservation of cultural features.

\section{Managing for contemporary cultural practices}

The International Union for Conservation of Nature (IUCN) classification system-from Category I to Category VI-represents a decreasing degree of naturalness and an increasing degree of 'culturalness' (Dudley 2008; see Chapter 2, Figure 2.1). It offers guidance to those designating or managing protected areas at the site or system level. In the 21 st century, the majority of protected areas across the world experience some level of human use, which can vary from 'leave only footprints' to subsistence resource use by indigenous peoples and communities living in or close to protected areas. 
The objectives for different IUCN categories help prescribe the type and extent of cultural use. Hence Category I (nature reserve and wilderness) protected areas encourage low-impact bushwalking and passive enjoyment. Category II (national park) protected areas are often promoted for their recreational and tourism values and some receive very high levels of visitor use in pursuit of these values (see Chapter 23). Research and education, especially at primary and secondary school levels, are also the hallmarks of a national park. Category III (natural monument or feature) relates to natural features, but they may be highly significant as sacred sites and thus receive high levels of visitation from pilgrims as well as from the general public. Category IV (habitat/species management area) may have low levels of cultural use, unless the species habitat is a culturally determined one-for example, the Chimborazo Fauna Reserve in Ecuador. This reserve was created in the late 1970s to provide for the reintroduction of Andean camelids whose populations had almost disappeared in the region. The Ecuadorian Government reintroduced vicuña (Vicugna vicugna) to the area surrounding the Chimborazo volcano and also introduced llamas (Lama glama) for local indigenous communities to raise and manage.

Category $\mathrm{V}$ areas (protected landscape/seascape) are places visibly shaped by the interactions of humans with the natural environment-these are biocultural or cultural landscapes. Their existence relies on processes that sustain this relationship, achieved through the role local and indigenous communities have as stewards (Brown et al. 2005). Ongoing cultural use of protected landscapes is critical to their existence. Category VI areas combine ecosystem conservation with traditional natural resourceuse management systems. Most of the area remains in a natural condition with a proportion subject to low-level non-industrial use of natural resources. While traditional ecological knowledge is applicable and combined with Western science in all categories, it generally has its highest level of expression in Categories V and VI.

A useful tool for protected area managers and conservation practitioners is the matrix created by combining the vertical management categories with the horizontal governance styles (see Chapters 7 and 8). This matrix framework recognises that protected areas are created and cared for by a diverse array of stewards. This tool and other events have reinforced an important shift in thinkingfrom the conventional view that protected areas are created and managed only by governments, to one that recognises that they are also places created and managed by communities, private organisations or individuals in diverse arrangements. All protected areas-from a strict nature reserve to an extractive reserve-are capable of being managed by any of the governance regimes. Countries are now encouraged by the IUCN to expand their national protected area systems by incorporating the full range of governance types (Kothari et al. 2013). The protected area matrix can potentially facilitate inclusion of the biocultural heritage paradigm - appreciation of the coevolution of nature and culture-in all management categories and governance options (Dudley 2008; Borrini-Feyerabend et al. 2013).

The Fifth World Parks Congress in 2003 produced the Durban Accord, which enshrined the rights and responsibilities of indigenous and local communities, and raised the profile of diverse governance regimes, in particular those involving collaborative and community governance (Brown and Kothari 2011). At the congress, the role of communities in creating and managing protected areas was, for the first time, a central part of the debate, launching significant work on the theme of governance. The topic of protecting biocultural/cultural landscapes and seascapes also featured prominently, explored in a workshop bringing out case study experience from diverse regions, and resulting in a book on a new approach to working with local communities in meeting conservation objectives that integrate nature and culture (Brown et al. 2005).

Alongside the Durban Accord, the congress produced a 'Message to the Convention on Biological Diversity', with specific recommendations related to the involvement of indigenous and local communities and rights-based approaches to conservation. Importantly, these points were subsequently taken up in the Convention on Biological Diversity (CBD) Programme of Work on Protected Areas (PoWPA), thus helping to shape policy in the countries which are signatories to the convention (Kothari et al. 2013).

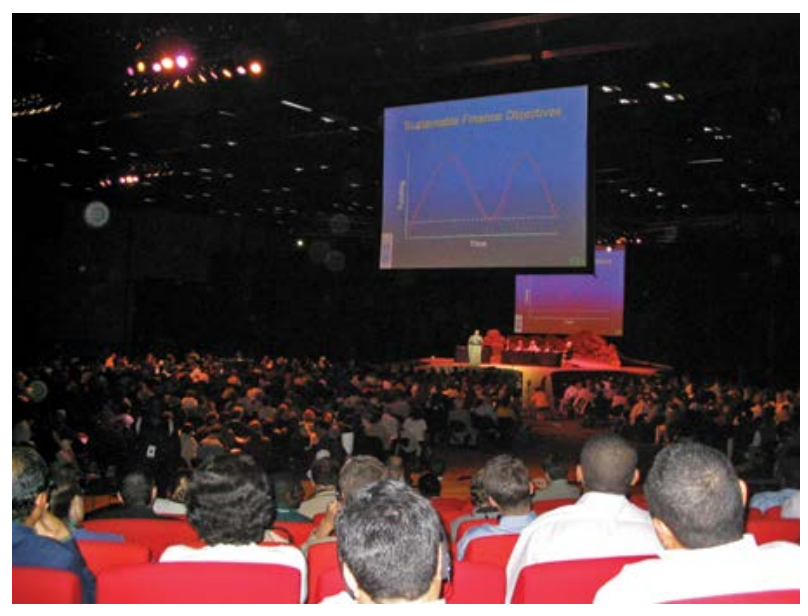

Plenary session of the 2003 Durban World Parks Congress, South Africa

Source: Graeme L. Worboys 


\section{Case Study 22.1 Ranger training by the Cofán people}

The Cofán people (or A'l) have been able to achieve stronger protection for their territory within the extensive Cofán-Bermejo Ecological Reserve in Ecuador, South America. They have trained a select group of indigenous rangers and tourist guides who are charged with patrolling the boundaries of the reserve and informing visitors about the key biodiversity protection mechanisms in place.
Under the leadership of Randall Borman, a multilingual shaman of the Cofán nation, they have been able to negotiate for environmental remediation of the oil-polluted riverine ecosystems of the headwaters of the Napo River watershed, including the Coca Falls (formerly San Rafael), one of the most photographed waterfalls in one of the most biodiverse ecoregions on Earth (Cepek 2012).
Appreciating and working with a diversity of cultures are now among the guiding principles in the administration and management of protected areas, with the realisation that protection of the natural and cultural world can be dependent on the support and knowledge of people living in or near protected areas. Local and indigenous communities once excluded now have a pivotal role to play as custodians of the landscape (Brown and Hay-Edie 2013). This reflects recognition that the stewardship practised by local and indigenous communities from antiquity has been important in retaining the very values that give the area its protected status (Rössler 2003). This trend of indigenous stewardship is illustrated with an example from Latin America (Case Study 22.1). This example highlights the increasing influence of community-driven initiatives for conservation 'from the ground up'. They contrast with the topdown approaches that characterised the declaration of protected areas in previous decades. The example also demonstrates indigenous cultural revival (Sarmiento and Hitchner in press) along with a more assertive participation by local cultural groups, mainly indigenous nations, at both the national political governance and the international intellectual leadership levels, and especially in the World Heritage program (Te Heuheu et al. 2012). Consideration of cultural uses and values is now a required step in conservation planning, and its importance is reflected in training and two-way learning programs (Case Study 22.2).

\section{Managing cultural use with integrative approaches}

Historically, conservation of nature through the formal designation of protected areas was driven, guided and sometimes controlled by ideals of the Western world (see Chapters 4, 5 and 7). It is now recognised that accommodating livelihood needs and recognising local and traditional ecological knowledge built over centuries to manage culturally modified landscapes are potentially ways to enhance conservation practices in protected areas of every designation. Protected areas are key elements in any strategy to conserve and sustain biodiversity in the landscape and seascape, and bridging the nature/ culture divide may be important for making protected areas meet human needs and future nature conservation challenges. We risk ignoring the full value of protected areas (Harmon and Putney 2003) unless we embrace a diverse array of values-natural and the tangible and intangible components of culture-in protected area planning, designation and management (Phillips 2003).

Three important trends in this direction are: creation of protected areas based on Category V; continuing progress in designation of World Heritage cultural landscapes in diverse geographical regions, particularly in nominations led by indigenous and local communities; and emergence of the concept of biocultural heritage.

\section{IUCN Category V protected areas}

IUCN Category V protected areas, long associated with the protected areas of Europe, have increasingly been taken up and applied in diverse regions of the world, in places like Andean South America, East Africa and Oceania (Brown et al. 2005; Dudley and Stolton 2012), including those associated with the protection of agrobiodiversity and food security (Amend et al. 2008). These relatively recent protected landscape/seascape designations typically draw on the Category $\mathrm{V}$ definition as presented in the IUCN guidelines and adapted to a specific national or provincial context. Following the 2008 review of IUCN protected area management categories, the following updated definition of Category $\mathrm{V}$ protected areas is included in the current version of the IUCN guidance:

A protected area where the interaction of people and nature over time has produced an area of distinct character with significant ecological, biological, cultural and scenic value; and where safeguarding the integrity of this interaction is vital to protecting and sustaining the area and its associated nature conservation and other values. (Dudley 2008:20) 


\section{Case Study 22.2 The integration of local cultural values into the management of Rwenzori Mountains National Park, Uganda}

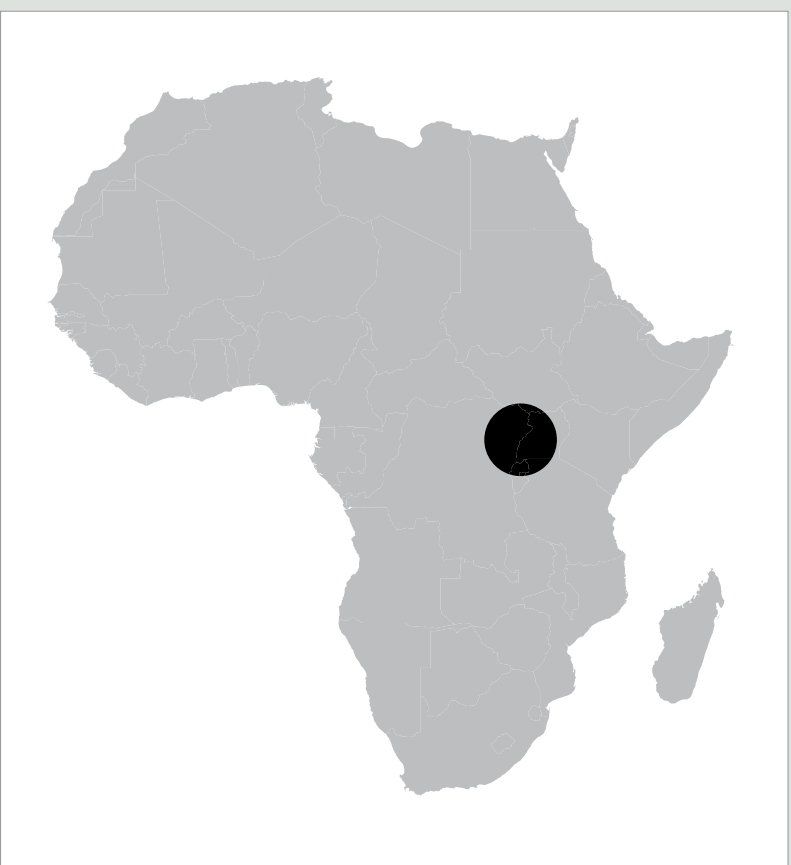

Figure 22.1 Indicative location on the African continent, Rwenzori Mountains National Park, Uganda

Source: US NPS

In 2006, Fauna and Flora International and the Uganda Wildlife Authority (UWA) began a partnership to integrate local cultural values into the conservation and management of the Rwenzori Mountains National Park. Conservation goals were not being met, however, due to lack of local and political support, and relations between the people and park managers remained difficult and distant. The Culture, Values and Conservation Project sought to improve this situation by recognising the importance of local values and interests for achieving conservation outcomes.

The principle underlying the project was that engaging communities by investigating their cultural values and working to integrate them into the management of the park would be more effective at creating local support and active engagement than describing the park's importance in terms of science and economics and explaining the need to protect it using Western values.

The Banyarwenzururu or mountain people have lived for centuries in the mountains, farming the foothills, harvesting resources in the forests and hunting in the highland moors and lowland plains. Social and political organisation is based on the mountain ridges that descend from the peaks to the plains. Each ridge is 'served' by a sacred site. Spiritual power originates with Kithasamba-who inhabits the snowcaps of the mountains-and protected areas pass to the King (Omusinga). From the King, power flows to clan chiefs (Ise' malhambo) and then to ridge leaders (Bakulu B'bulhambo) responsible for ceremonies to purify the ridges, protecting and bringing good fortune to the community. Ridge leaders also ensured appropriate and respectful behaviour of people harvesting or hunting in the mountains and hence sharing space with the gods.
Although not understood as conservation in the modern Western sense, these institutions and cultural norms helped sustain natural and social order. Ridge leaders effectively managed resource use by the ridge community in the forests above their ridge. Park management did not comprehend the effectiveness of this traditional governance working across ridges and they prevented access to the sacred sites, weakening the cultural connection between the people and the mountain.

To integrate Banyarwenzururu culture into the park, the project:

- introduced the wardens and rangers to the basic ideas of the approach and helped build capacity and interest in a cultural values approach

- engaged UWA's protected area planning team to integrate assessment of cultural values into formal park planning processes

- approached community groups and institutions to encourage them to work with the park and helped them assess the values of the Rwenzori Mountains that were important to them

- facilitated negotiations to help communities and park managers agree on key values for the park that could support both community and park interests and objectives

- supported local champions of the values and practices linking local people to the park and helped them engage with park staff to integrate local values into day-to-day park management

- helped UWA review their policies, practices and programs from a cultural values perspective using achievements, problems encountered and lessons learned

- encouraged cultural institutions and park authorities to negotiate mechanisms for collaboration that harmonised traditional and official interests

- helped draft memoranda of understanding and revise park management plans, explicitly reflecting agreements on cultural values.

Adopting a cultural values approach will not address all the challenges faced by conservation, but it offers promise for demonstrating mutually beneficial incentives for managing protected areas, surrounding landscapes and natural resources, and for creating a broader constituency for conservation that will protect biodiversity sustainably, more effectively and more equitably (Infield and Mugisha 2013).

- Mark Infield and Arthur Mughisa, Fauna and Flora International 
Recent examples from diverse regions are illustrative. Canada's Province of Quebec has created a designation called paysage humanisé (or 'living landscape') in keeping with Category $\mathrm{V}$ and modelled after the regional nature parks of France and Belgium. The Province introduced the designation as a means of increasing biodiversity conservation, particularly on private lands, while encouraging sustainable rural development (Blattel et al. 2008). Brazil's system of protected areas includes the Area de Proteçao Ambiental (or 'environmental protection area'), a designation similar to Category $\mathrm{V}$ (Lino and Britto de Moraes 2005). In Ecuador, with the introduction of a new Law of Cultures in 2014, the potential creation of an Ecuadorian Heritage Cultural Landscape designation is being explored. Such a designation would be based on values of Ecuadorian identity, sustaining biological as well as cultural diversity, and declaring heritage in the Andean sense of 'patrimony' worth protecting (Sarmiento and Viteri in press).

Recently, the expanded Dhimurru Indigenous Protected Area in Australia was formally recognised by the Australian and Northern Territory governments as a Category $\mathrm{V}$ protected area. The Indigenous Protected Area (IPA) now comprises some 550000 hectares, incorporating extensive areas of land and sea, consistent with coastal Aboriginal people's holistic view of land and sea as indivisible components of their traditional country (Gilligan 2006). The Dhimurru IPA management plan specifically spells out its match with the Category $\mathrm{V}$ definition and guidelines.

Establishment of the Resguardo Indigena (or Indian reservations) occurred during the Spanish colonisation of Colombia. Today 15 reservations are the communal property of local ethnic groups of the highlands in the Colombian Massif. They cover 27 per cent of the country, and include 43 per cent of its natural forest areas (SIAC 2014). In recognition of their biodiversity values, some of the reservations are classified as Reservas Naturales de la Sociedad Civil (or Nature Reserves of Civil Society). The nature reserves are recognised as part of the National System of Protected Areas (SINAPS) once they have been legally registered (SINAPS 2014).

Objectives for managing these culturally defined ecosystems include maintaining cultural management systems where these have a unique associated biodiversity. Continual intervention is needed because the ecosystem has been created or at least substantially modified by management.

\section{Cultural landscapes}

A major shift to facilitate the incorporation of cultural themes in nature conservation occurred in the USA in 1981, when the US National Park Service (NPS) recognised cultural landscapes as a specific type of cultural heritage, together with publication of Cultural Landscapes: Rural historic districts in the national parks system (Melnick 1984), which set out criteria for identifying and defining cultural landscapes. Since then, the NPS has provided intellectual and on-ground leadership through its register bulletins, publications, its own research, interpretation, treatment and management of cultural landscapes within the protected area system (Conservation Studies Institute 2005). The NPS (2014) defines a cultural landscape as 'a geographic area (including both cultural and natural resources and the wildlife or domestic animals therein), associated with a historic event, activity, or person or exhibiting other cultural or aesthetic values'.

When the category of 'Cultural Landscapes' was included within the framework of the World Heritage Convention in 1992, a new opportunity was created to inscribe sites that embody outstanding examples of the interactions between humans and nature and contain diverse tangible and intangible values (Rössler 2005; Finke 2013). Recent studies have documented the considerable overlap between Category V protected areas and World Heritage Cultural Landscapes (Phillips 2003; Rössler 2005; Finke 2012). The three categories that the UN Educational, Scientific and Cultural Organisation (UNESCO) has adopted — that is, clearly defined landscape, organically evolved landscape and associative landscape (see Chapter 4) - have developed principles that protected area managers can adapt and use (UNESCO 2009).

The associative cultural landscape category highlights the cultural, spiritual and aesthetic values of natural sites and landscapes in protected areas. The first two World Heritage sites to receive designation as associative cultural landscapes were Tongariro National Park in New Zealand and UluruKata Tjuta National Park in Australia_-both major sacred natural sites for indigenous peoples. The concept applies equally well to protected areas valued by the public for other than sacred reasons_ such as for their value as places of spiritual renewal and artistic inspiration and as icons of national and local identity. The Lake District National Park in the United Kingdom, for example, enshrines for the British people the poetry and art of the English Romantic Movement with its celebration of nature and the human spirit, as exemplified in the works of poets and artists such as William Wordsworth and John Constable 


\section{Box 22.1 Recommendations for fostering community stewardship of cultural landscapes}

Cultural landscapes-the result of a long and complex relationship between people and natureare with us today because of the past and presentday stewardship of those communities living in and near them. Sustaining this relationship into the 21st century will require approaches to conservation that embrace a wide range of governance and management options, and build on the human impulse for stewardship. A session on community stewardship at a 2012 conference at Rutgers University on 'Cultural Landscapes: Preservation challenges in the 21st century' explored these issues through case studies from diverse regions. Through presentations and discussion, a number of recommendations emerged. Supporting indigenous and local communities in stewardship of cultural landscapes will require new partnerships that take into account the need to:

- sustain the core values underlying stewardshipsuch as tradition, language, respect and loveensuring that these are reflected in education of the next generation and translated into the policies affecting communities

- reinforce the central role of communities not only in management but also in governance, whether as governance by communities or in collaborative relationships, and manage adaptively

- honour the importance of distinctive spiritual relationships with the land (enshrined as a human right by the United Nations) and the associated traditional practices and sacred places that are held in trust for the living, the dead and the unborn

- recognise traditional knowledge alongside Western systems of science, ensure that it informs management policies, and support communities in transmitting this knowledge and associated practices (such as indigenous languages, food ways, water management systems and handicrafts) across generations in ways that foster identity and pride

- support and develop livelihood opportunities, recognising the dynamic nature of this challenge in the context of globalisation, so that young people have the option of living in the communities from which they come (Brown in press [a]).

(Mallarach 2008). The Chinese treasure the spectacular peaks and twisted pines of Huangshan National Park as sublime subjects of poetry, art and photography (there is even an important school of landscape painting named for Huangshan) (Pungetti et al. 2012), and the Japanese regard Mount Fuji as a symbol of Japan (Bernbaum 2006).

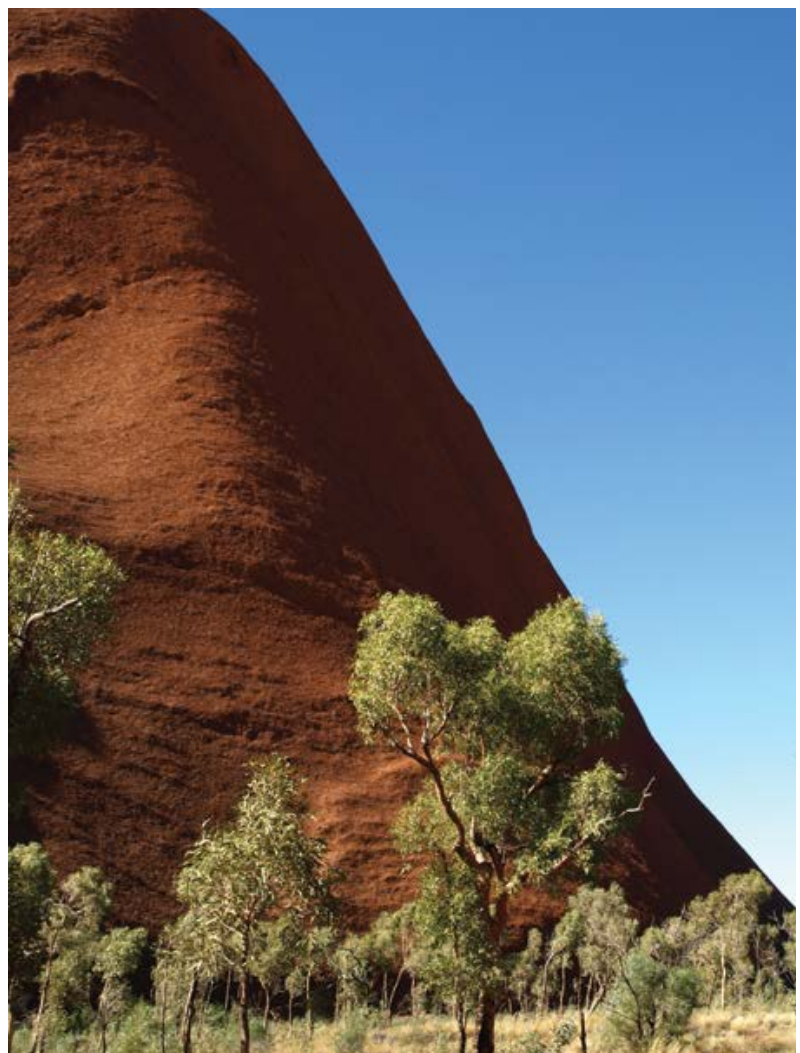

Uluru-Kata Tjuta National Park, Northern Territory, Australia

Source: Graeme L. Worboys

UNESCO has published a handbook for the conservation and management of World Heritage cultural landscapes organised around six guiding principles that can be adapted for application to the wider task of managing cultural uses in protected areas (Mitchell et al. 2009).

1. People who value the cultural landscape, no matter how distant from it, are important stakeholders.

2. Successful management is inclusive and transparent, and governance is shaped through dialogue and agreement among key stakeholders.

3. The values of the cultural landscape are based on the relationship between people and the environment.

4. The focus of management is on retaining the values of the cultural landscape, both natural and cultural.

5. Management of cultural landscapes is integrated into a wider context of larger ecosystems and cultural linkages.

6. Successful management contributes to sustainable means of support for local communities who protect the landscape and its values.

Recommendations for fostering stewardship are presented in Box 22.1. 


\section{Case Study 22.3 Russia's journey towards recognising biocultural heritage}

The history of nature conservation in Russia is closely aligned with dramatic changes in the political climate. The modern system of protected areas-Zapovedniks (meaning forbidden or protected) - began in 1916 under Tsarist rule and aimed to preserve models of intact nature (mostly by excluding people) and to encourage research into nature. The Bolsheviks assumed power after the Russian revolution and in 1922 the Union of Soviet Socialist Republics (USSR) was formed. Under Lenin, Zapovedniks received support from the government and local communities. Although the general population did not see protected areas as part of their everyday lives, scientists often worked with local communities who appreciated their efforts.

This changed dramatically when Stalin came to power. He saw Zapovedniks as enemies of socialism and opened them up for large-scale resource exploitation. During the 1970s and 1980s, the protected area system expanded but community support waned. After the USSR was dismantled, funding for nature conservation virtually disappeared and protected areas turned to local communities and regional governments for financial support. Getting that support meant a change in approach.

The historical exclusion of people caused conflict with local communities-angry they could no longer enter the park and use its resources. While this was partly overcome through effective environmental education programs with schoolchildren, developing collaborative partnerships with local communities has proved to be more fruitful.

The past decades have seen greater integration of Zapovedniks into the local socioeconomic structure by supporting rural agriculture and recognising the value of traditional knowledge in managing nature.

An example of the latter is employment of 'ranger beekeepers', who have the task of managing populations of wild bees in the Shulgan Task Zapovednik in the Ural Mountains. Knowledge about wild bee keeping goes back about 1000 years and is passed down through men in the family. Their knowledge is being used to maintain wild populations in artificial hives and is valuable for maintaining the wild bee population as well as the associated traditional knowledge.

Source: Williams (2003)

\section{Biocultural diversity}

Biocultural diversity is an inclusive term meaning the diversity of life in all its manifestations-biological, cultural and linguistic_-interrelated within a complex socio-ecological adaptive system (Apgar et al. 2011). This more people-centred paradigm is becoming increasingly accepted across the conservation spectrum, but is most prevalent in situations where cultural use is a defining feature of the protected area, such as Indigenous Peoples' and Community Conserved Territories and Areas (ICCAs), Category V and VI protected areas, and where there is collaborative management involving a local ethnic group—-for example, IPAs in Australia.

There are strong synergies between cultural landscapes and biocultural landscapes (also biocultural diversity or biocultural heritage), and distinguishing between them may not be that helpful from a management perspective. The former term, however, is seen by many as privileging Western protected area thinking and does not adequately reflect the interaction of nature and culture. The alternative term, biocultural heritage, explicitly recognises the social and cultural context in which ethnic societies across the world have transformed the nature/culture boundary through their long-term management. In paradigms of integrating nature and culture, biocultural heritage is synonymous with cultural heritage.

The concept of biocultural heritage seeks to integrate the collectively gained knowledge of indigenous and local communities with scientific approaches to nature

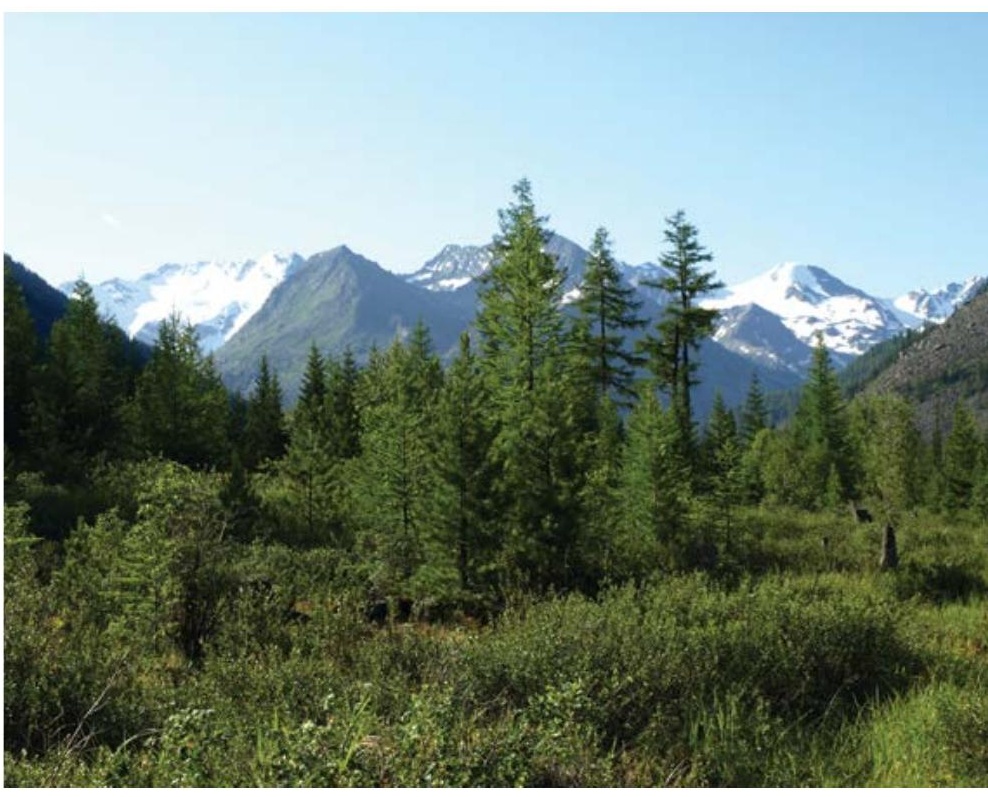

Katunsky Zapovednik, Altai Republic, southern Siberia, Russia

Source: Graeme L. Worboys

conservation management. This traditional knowledge encompasses a diverse field of information about, for example, crop and livestock varieties, medicinal plants, wild foods and wild crop relatives. Application of traditional knowledge in the use and management of natural resources has created a complex symbiotic system that has lasted centuries, even millennia (Berkes and Folke 1998). The development of biocultural heritage approaches in Russia, for example, is described in Case Study 22.3. 


\section{Case Study 22.4 Potato Park (Parque de la Papa)}

An example of an indigenous biocultural heritage area is the Potato Park (Parque de la Papa) in highland Peru, where local empowerment of some 6000 people of five Qeshwa communities around the town of Pisac, in the sacred Valley of the Inka, has transformed the area of the Sacaca, Chawaytire, Pampallaqta, Paru Paru and Amaru into one cohesive community-based enterprise. Before the Parque de la Papa, they were five groups, but now with the parque, they are one group. All projects are managed collectively by the communities to ensure effective participation and sharing of benefits.

Legally, the communities form part of the Association of Communities of Potato Park, which is the communal administrative body of the park. This ANDES Association, administering the rules and regulations regarding exploitation of natural resources within the biocultural heritage area, becomes de facto planner, manager and ranger of the reserve-thus, it is a true steward. Its members apply Andean principles of duality, reciprocity and balance. To protect their rights and their role as a centre of potato origin and diversity, the park's communities promote environmentally focused nature conservation.

Within Andean communities, customary laws have always placed an important role on the administration of biodiversity (including genetic resources, species and ecosystems), and above all, in creating equity, balancing power and maintaining free access to the resources of Pacha Mama (Mother Earth), and in the resolution of conflicts. The fundamental principles that make up the Andean cosmological vision are the foundation of patterns of behaviour and customary laws. In the case of the Potato Park, the epistemological bridges prescribed by the biocultural heritage area approach link traditional and science-based understandings of the multiple functions of agricultural biodiversity-including the close interaction between wild and domestic plant and animal diversityand how they sustain local livelihoods (Argumedo 2008).

A considerable portion of biocultural diversity today is found where indigenous peoples continue to live in ancestral territories (Loh and Harmon 2005). Therefore it is important to understand the underlying community processes that nurture biocultural diversity, which are rooted in historical interactions of people and nature, and the goals of which are the self-determination and wellbeing of communities within the environment in which they live. Understanding and supporting the self-determination of indigenous peoples are therefore important strategies for ensuring that biocultural diversity continues to be nurtured (Apgar et al. 2011). An example of a designated area aimed at conserving biocultural diversity by nurturing both the environment and the people is given in Case Study 22.4.

These developments and others during the past decade demonstrate the value of the landscape approach in conservation policy and practice, reaching beyond the existing boundaries of protected areas in ways that encompass diverse governance regimes and engage communities in nature stewardship (Brown in press [b]). They lay the groundwork for strategies that bring more closely together 'nature conservation policies' and those of 'territorial planning policies', affecting not only the broader landscape but also the national identity affirmation affecting local indigenous people. A key challenge remains in understanding the complex array of linkages between the two and, as per the IUCN Category $\mathrm{V}$ definition, safeguarding the integrity of this interaction, recognising that protected landscapes involve process, as well as place, and that sustaining a relationship between people and the land is basic to

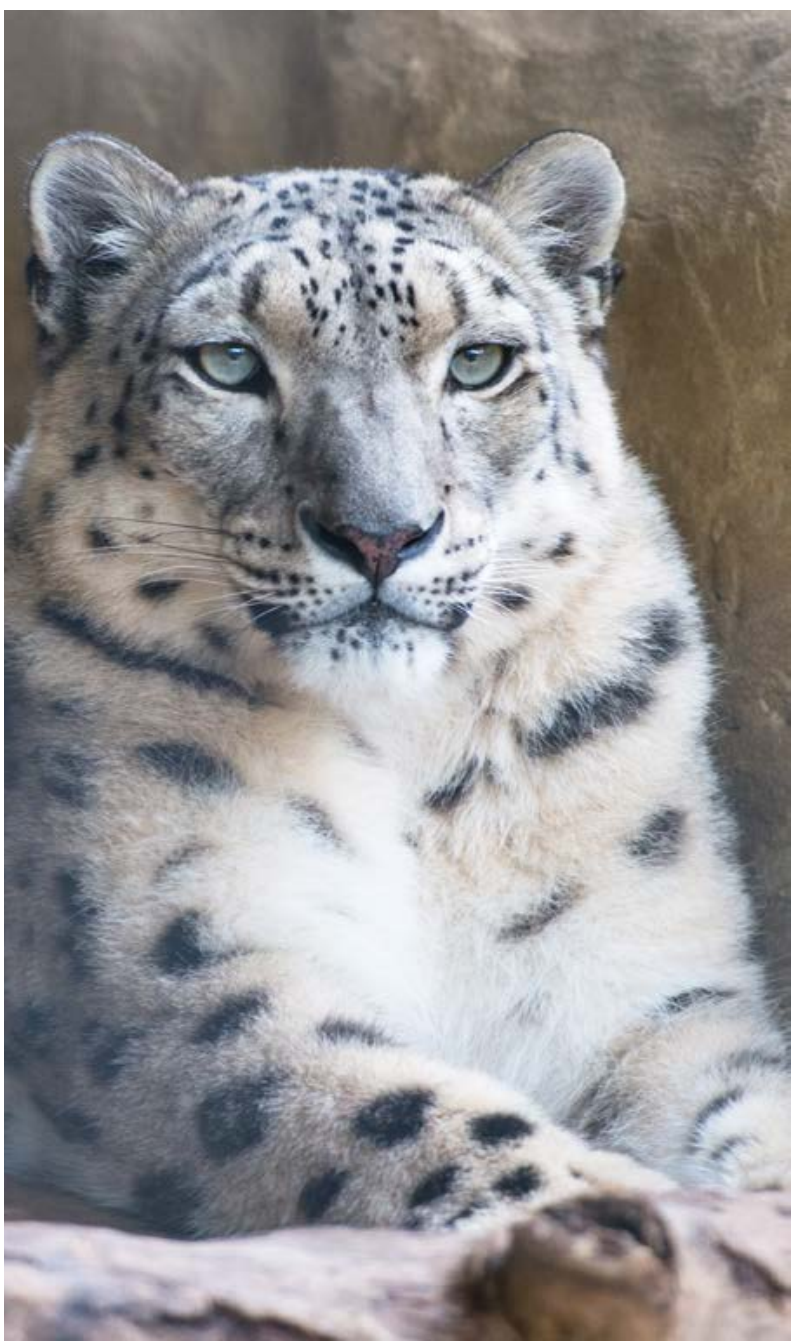

Snow leopard (Panthera unicia)

Source: Graeme L. Worboys their future. An example of this important integration is presented in Case Study 22.5. 


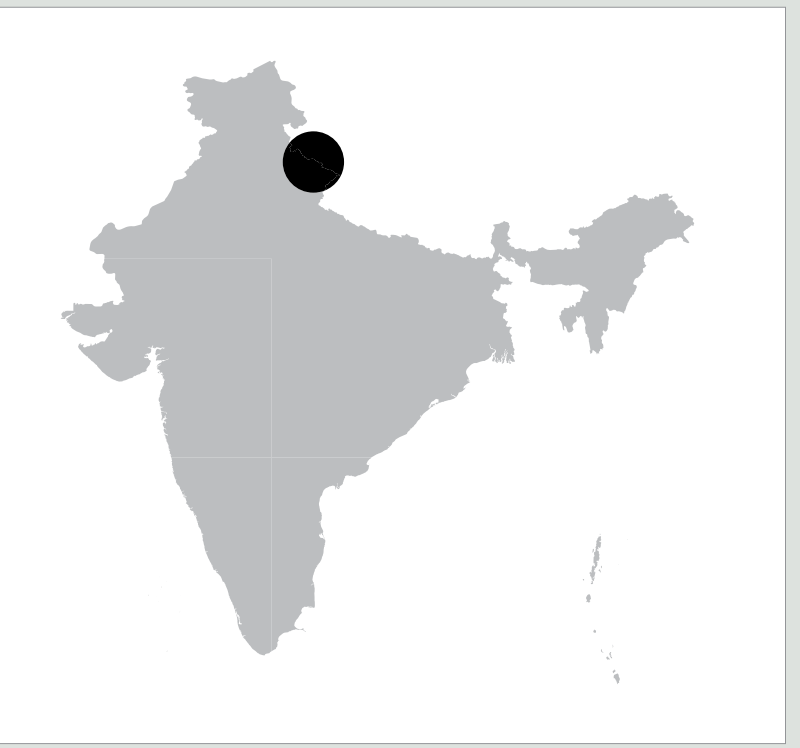

Figure 22.2 Indicative location on the Indian subcontinent, Nanda Devi Biosphere Reserve, India Source: US NPS

The Nanda Devi Biosphere Reserve, a World Heritage site and the second declared biosphere reserve in India, occupies a special place in the higher Himalayan region of the country. Tolchha and Marchha communities of the Bhotiya ethnic group are the main inhabitants of the Niti and Mana valleys in the Chamoli region of Garhwal that form the buffer zone of the reserve. These two communities practice transhumance and have two settlements, one at a higher and the other at a lower altitude. The Tolcha and
Marchha communities have been the main custodians of this cultural and spiritual landscape since before the area was declared a biosphere reserve. The entire reserve is treated as a cultural landscape. The highest peak in the area is Nanda Devi, which is recognised as a prominent Hindu goddess. Small temples of Nanda Devi are present in all villages in the reserve. Local people worship the mountain goddess and protect the forests of the area. Livestock rearing used to be their main livelihood option, but in the past few years, locals have shifted to medicinal and aromatic plant cultivation and ecotourism and home-stay alternatives to ensure minimal damage to their fragile environment. Only sustainable utilisation of forest resources-be it of fuel wood, fodder or medicinal and aromatic plants-is permitted by the locals. Village women practice rotational harvesting of resources from different forests to ensure proper regeneration of species and conservation of habitat for many unique wild flora and fauna, including the snow leopard (Panthera unicia), monal pheasant (Lophophorus impejanus) and musk deer (Mochus chyrsogaster). Urbanisation has still not affected the life of people dwelling in these villages, and they still follow a subsistence lifestyle.

The Kedarnath Wildlife Sanctuary is located in the Rudraprayag district of Uttarakhand State, and is bounded to the north by a series of ancient Hindu shrines. It is a managed nature reserve with five popular Shiva shrines, locally called the Panch Kedars: Kedarnath, Rudranath, Tungnath, Gopinath and Madhamaheshwar. These shrines are visited every year by a large number of pilgrims from India and abroad.

- Shalini Dhyani and Deepak Dhyani, Project Scientists, Uttarakhand, India

\section{A manager's road map for integrating culture and nature}

The effectiveness of a conservation program that emphasises the integration of nature and culture depends on a clear communication strategy. It should address the changing paradigm of cultural landscapes and biocultural heritage and invigorate the emergence of new paradigms of an increasingly urban world. For many conservation managers, culture and nature are no longer parts of a dichotomy in the decision-making process to administer an area. The following tenets of site management practice are recommended to ensure an integrated approach (Taylor and Lennon 2012).

- Acknowledgment of the interface between culture and nature: There is a new understanding of the link between nature and culture, where healthy landscapes have been shaped by human interaction and biological diversity often coincides with cultural diversity.
- Expressions of cultural diversity and people's identity as a response to the landscape: There is a new consideration of intangible values, social inclusion, community consultation and heritage as major anchors for cultural identity positioned at the heart of community development.

- Involvement of biodiversity through traditional practices in the landscape: The communities in which the integrity and diversity of language, social institutions, cultural traditions and land-use practices are maintained also contribute to the diversity and resilience of their surrounding ecosystems.

- Sustainability goals for land use, climate amelioration and livelihood protection: These living landscapes play a vital role in sustaining agrobiodiversity as well as inherent wild biodiversity values, ensuring ecosystem function, and supporting livelihoods and food security with a much reduced carbon footprint. 


\section{- Traditional ecological knowledge systems:} Retention of indigenous knowledge is dependent on its use; it is not solely embedded in people's minds, but also in the environment with which they engage.

- Intangible heritage expressed through rituals and lifestyles: Most ecosystems and landscapes must be seen as coupled social-ecological systems whose resilience depends also on these practices.

- Clear distribution of tasks and observance of the conservation matrix of sites with differential governance regimes: The repositioning of heritage as part of community development has brought changes, even in the Western world; the values of heritage no longer reside exclusively in its physical fabric and form, but in intangible concepts that by their very nature are in constant flux, and should be part of every conservation category with each governance type.

\section{Managing for cultural spiritual values}

The cultural and spiritual values people hold lead to strong feelings that can be harnessed to generate support for protected areas through community engagement and participatory processes that give greater emphasis to these values. One important issue that frequently comes up is management of wilderness areas. In addition to its scientific value for the preservation and study of ecosystems and biodiversity, wilderness in many societies today has great cultural and spiritual value. For many people, wilderness areas represent places of spiritual renewal, where they can return to the source of their being and recover the freshness of a new beginning (see Chapter 4). In Western societies the idea of wilderness as an example of unspoiled nature calls forth visions of the Garden of Eden and symbolises for many humanity's natural state of freedom. In East Asian cultures such as the Chinese, Japanese and Korean, landscape paintings of mountains and rivers evoke the Dao-the spiritual essence of reality that flows through nature (Bernbaum 1997). Appeals to these kinds of cultural and spiritual values are among the strongest sources of support that managers can draw on to engage and involve the general public in developing and implementing measures to establish and preserve wilderness areas.

Conversely, indigenous peoples regard wilderness areas not as pristine untouched spaces, but as places they have lived in and used for centuries or thousands of years, subtly or otherwise altering the appearance of the natural environment. They value these places for reasons that need to be identified and integrated into protected area management to address their concerns and aspirations.

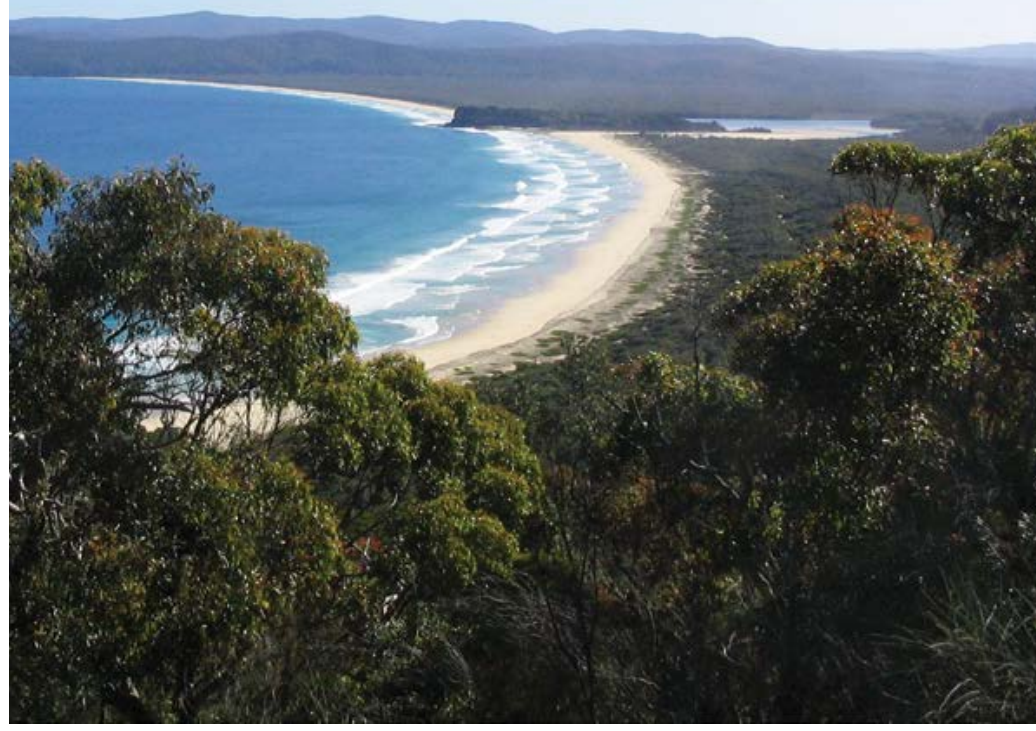

Disaster Bay and the proclaimed Nadgee

Wilderness Area in the centre-left distance (part of the Nadgee Nature Reserve). The image was taken from Ben Boyd National Park, southern New South Wales, Australia. The area is very important to local Aboriginal communities and has been frequented by Aborigines for thousands of years.

Source: Graeme L. Worboys

Another, related way of engaging the public is to work with non-governmental organisations (NGOs) that have an interest in a particular protected area or protected area management in general. Appeals to cultural and spiritual values can be particularly effective in galvanising public action and support for major needs and concerns. A striking example of this occurred in the 1960s when the US Congress was prepared to grant permission to dam the Colorado River in Grand Canyon National Park. The deal was all but done when the Sierra Club, an important environmental organisation in the United States, ran advertisements in newspapers around the country asking, 'Should we also flood the Sistine Chapel so tourists can get nearer the ceiling?' The implicit comparison with desecration of a famous sacred site of great aesthetic and religious value sparked widespread outrage. Congressmen were inundated with letters of protest from the public that forced them to reverse their decision and cancel construction of the dam (Nash 2001).

Cultural and spiritual values can also make it difficult to get things done. Managers need to deal with conflicts between the interests of their protected areas and those of various sectors of the general public, as well as conflicts among different groups which value protected areas 
for different reasons. For example, Rocky Mountain National Park in the United States wanted to set up a series of wayside signs highlighting the cultural and spiritual significance of mountains around the world. A small sector of the public vociferously objected, demanding an exclusive focus on the mountains in the park that they valued above all others as their mountains, and succeeded in killing the project. A major role of protected area managers is to maintain the support and interest of the public even when decisions go against the interests of some stakeholders.

Cultural associations must be maintained to keep the associative values alive. This requires cooperation and collaboration between community group leaders, knowledge-holders and protected area managers. It may include education programs, seasonal activities, intergenerational meetings or cultural camps where knowledge is passed on to younger generations, and festivals to transmit rituals and crafts, including teaching and using local language/dialects. These give a sense of pride in local costume and cuisine and help maintain ritual and religious behaviour.

In managing cultural heritage in protected areas, managers must know what cultural values occur in their landscapes and ensure that management regimes protect and enhance both the intangible expression of these values and their physical evidence. But like culture, values are dynamic: they evolve and change over time due to external influences. Management strategies must be cognisant of changing values in local communities. For example, until the 1970s in Australia, Aboriginal people were so disempowered they rarely spoke out about the impacts of developments on their sacred sites. Today, young Aboriginal people are much more vocal and influential about what happens within the nation's protected areas.

Training of staff in managing conflict around cultural and spiritual values is essential. As with any conflict resolution, this requires respect, a capacity to listen and an ability to create a situation in which different parties can find a solution themselves (see Chapter 14). The following groups can provide useful resources and assistance for training programs and other matters involving the cultural and spiritual values of sacred natural sites and cultural landscapes:

- IUCN World Commission on Protected Areas (WCPA) Specialist Group on Cultural and Spiritual Values of Protected Areas

- Sacred Natural Sites Initiative

- Delos Initiative on sacred natural sites and cultural landscapes in technologically developed societies
- Ramsar Culture Network

- World Heritage Centre

- Alliance for Religions and Conservation

- Forum on Religion and Ecology

- Cambridge Centre for Landscape and People, a focal point for research on the cultural and spiritual values of landscape and nature

- Sacred Land Film Project

- The WILD Foundation

- Community Management of Protected Areas Conservation Programme (COMPACT).

\section{Managing cultural use of sacred sites}

Sacred sites are viewed and revered in a multiplicity of ways-for example, as centres of the cosmos; places of power; abodes of deities, ancestors and spirits; sources of water, life and other blessings; symbols of identity; or places of revelation, contemplation and inspiration. Through the views they have of sacred sites and the beliefs and practices associated with them, people of different cultures and traditions, both modern and traditional, believe they experience a deeper reality that gives meaning and vitality to their lives, linking them to something greater than their individual selves (Verschuuren et al. 2010).

Sacred sites can be places created by humans, such as Macchu Pichu, the statues of Rapa Nui (Easter Island) or churches and monasteries belonging to different religions. Such places are often situated in dramatic natural settings and sacred sites frequently combine both natural and cultural elements.

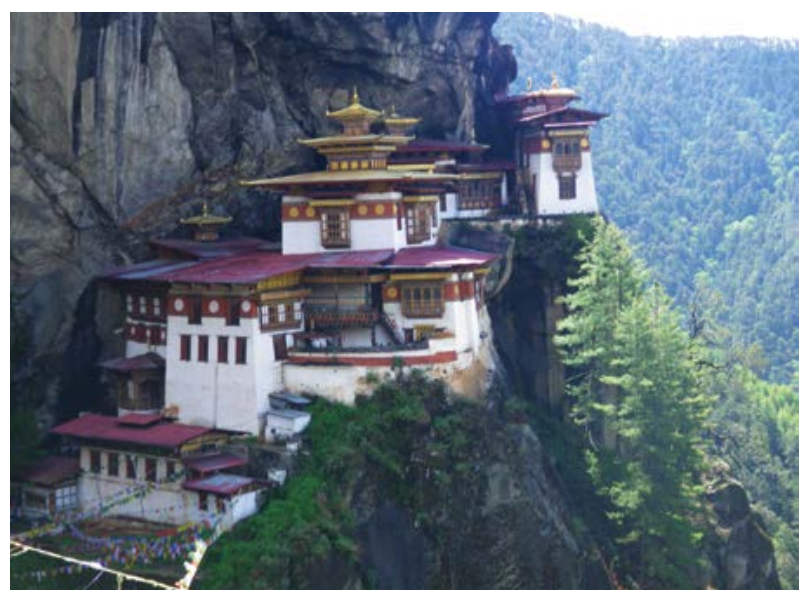

Taktsang Monastery (Tiger's Nest), one of Bhutan's most sacred and well-known Buddhist sites Source: Sue Feary 
Features of the natural environment such as mountains, waterholes or groves of trees can be sacred to indigenous and tribal cultures whose connection with the natural environment is fundamental to their cultural identity. The sacredness of a place in some cases resulted in protection of its biodiversity, and the links between indigenous/tribal cultural practices and conservation of biodiversity are being increasingly recognised. Natural sacred sites are, however, vulnerable to desecration through ignorance, inadequate legislation and injustice. Not surprisingly, recognition and protection of natural sacred sites have been a strong focus of international agencies such as the IUCN and UNESCO, leading to expansion of cultural heritage definitions to include intangible heritage (see Chapter 4).

Many protected areas set aside for biological and scientific reasons include natural features that have special cultural and spiritual importance for local communities and indigenous traditions, as well as for followers of mainstream religions who revere them as places of pilgrimage and contemplation. In some cases, the entire protected area is a sacred natural site-for example, Tongariro National Park in New Zealand and Mount Taishan in China. In addition, some protected areas are included within larger sacred natural sitesfor example, parks and biosphere reserves in the Indian Himalaya, where the entire mountain range is regarded as sacred in Hindu tradition.

Sacred natural sites are distinguished from other features of the environment by virtue of their association with intangible values: ancient webs of myths, beliefs and practices that envelop them and link local communities, indigenous traditions or mainstream religions to them. The Hopi, for example, regard the San Francisco Peaks of the American south-west as the abode of the katsinas (or kachina) - ancestral spirits whom they invoke and invite to bring life-giving rain through ceremonial dances they perform at their villages on mesas within sight of the sacred site. Hindus from throughout India believe that Shiva, one of the three forms of the supreme deity, dwells on the unclimbed summit of Mount Kailas in Tibet and many of them aspire to go on pilgrimage to make a ritual circumambulation of the sacred mountain.

The IUCN has published guidelines for protecting sacred natural sites in protected areas. The guidelines identify six general principles:

- recognise sacred natural sites located in protected areas

- integrate sacred natural sites into planning processes and management programs
- promote stakeholder consent, participation, inclusion and collaboration

- encourage improved knowledge and understanding of sacred natural sites

- protect sacred natural sites while providing appropriate management access and use

- respect the rights of sacred natural site custodians within an appropriate framework of national policy (Wild and McLeod 2008:21).

Another set of guidelines appears in the report of a 2006 UNESCO conference held in Tokyo, which highlights some additional principles for protected area managers to consider when managing natural sacred sites:

- the need for voluntary participation of local people in conserving sacred natural sites

- the importance of not putting pressure on local communities to compromise the secrecy of their natural sites

- allowing the harvesting of plant and animal species for ritual purposes

- utilising both modern science and traditional knowledge in the conservation and management of sacred natural sites

- establishing buffer zones around sacred natural sites and monuments to help protect them and allow for traditional activities

- the need for training and capacity-building programs in managing sacred natural sites and developing cultural sensitivity and social skills in interacting with local communities (Schaaf and Lee 2006).

These principles focus on sacred natural sites that have particular importance for local communities and indigenous traditions. Most natural sites sacred to indigenous and local communities have local significance and have meaning to fewer people when compared with mainstream religions. Furthermore, the location of such sacred places and the knowledge associated with them are often kept secret and may be known to only one person, such as in Australian Aboriginal society.

Custodians in indigenous traditions and local communities generally come from the immediate vicinity of a particular site. The position is often handed down through a family, which may well have economic as well as spiritual and cultural interests in the site, considering it their personal possession and valuing it as their source of livelihood. 


\section{Case Study 22.6 An integrated approach to the management of Mount Athos}

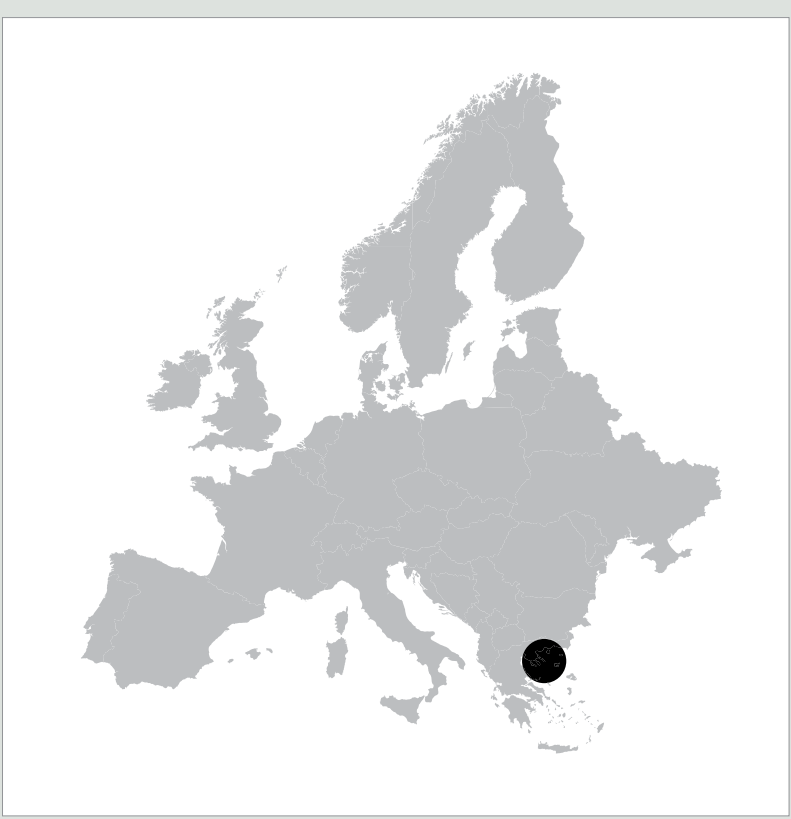

Figure 22.3 Indicative location in Europe, Mount Athos, Greece

Source: US NPS

In the north of Greece, the third peninsula of Halkidiki is dominated by the cone of Mount Athos, rising steeply to 2033 metres. The Athonite Peninsula, heavily wooded with Mediterranean forests and with high biodiversity, hosts 20 historic Eastern Orthodox monasteries and their dependencies with a millennial living tradition-cultural and spiritual. That is why the area was designated in 1988 as a World Heritage site for both nature and culture, and recently as a Natura 2000 protected area in its entirety. Until now, Mount Athos has been managed by its monasteries and their vibrant monastic brotherhoods in an essentially autonomous manner, with limited interventions by the Greek state through public services.
In 1994, when Prince Philip, president at that time of the World Wide Fund for Nature (WWF) International, visited Mount Athos, he tried to convince the holy community of the need for an integrated approach to the management of the peninsula in order to safeguard its rich natural and cultural heritage. Much later, a UNESCO mission to Mount Athos in 2006 identified the same need and the World Heritage Committee intervened strongly to promote the concept. In 2010, the integrated approach was accepted by the holy community, which represents the 20 sovereign monasteries, and in December 2012 it approved a preliminary study on the 'strategic framework for the conservation and management of the cultural and natural heritage of Mount Athos', prepared by a group of scientists and monks, coordinated by Thymio Papayannis. This preliminary document reviews the situation in Mount Athos and the challenges and threats it presents. It formulates a set of principles on which the entire management initiative should be based. And it indicates the priority areas to be addressed by the main study.

During 2013, the preparation of the final management study was launched in a positive climate of cooperation. Although the holy community maintains the initiative for the integrated approach to the management of the Athonite Peninsula, the Greek Ministry for Culture and the Ministry of Environment, as well as the World Heritage Centre, work closely with the monastic authorities to ensure wise management and effective conservation of this unique site, based on sound science and respect for the spiritual traditions of Mount Athos. An essential part of the exercise will be the development of an action plan that will ensure the effective implementation of the management study's recommendations and proposals. In this spirit, at the end of August 2013, an international and multidisciplinary workshop was held in Thessaloniki with the participation of the three sides (UNESCO, Greek ministries and the holy community), who debated the basic principles and contents of the integrated management study and reviewed its specifications.

- Thymio Papayannis
Numerous major natural features and protected areas also have great cultural and spiritual importance for mainstream religions and the general public-for example, Mount Fuji for Buddhism and Shintoism, as well as the Japanese people; and the peninsula of Mount Athos for Eastern Orthodox Christianity and much of the Greek public. These sites have important characteristics and requirements that differ from sacred natural sites associated with indigenous and tribal religions (Case Study 22.6). In the following sections, we examine ways in which protected area managers can work with mainstream religions to manage sacred sites, whether they are natural or built sites.

\section{Managing sacred sites by involving mainstream religions and the general public}

As discussed above, practices and beliefs (intangible heritage) associated with sacred sites of mainstream religions can differ from those associated with sites sacred to indigenous and local communities, with major implications for protected area management. The most obvious difference is the number of people for whom a site is sacred. Natural sites sacred to mainstream religions, such as Mount Sinai in the Saint Katherine Protectorate (an Egyptian national park) or Jebel Musa in the Saint Catherine's Area World Heritage site, Morocco, can have importance for millions of religious adherents and attract visitors from around the world in huge numbers, posing both challenges for protected area management 
and opportunities for disseminating messages of environmental conservation based on religious ideas. Many natural sacred sites of mainstream religions are revered places of pilgrimage, drawing large numbers of pilgrims from far away with little connection to or knowledge of local communities and environmental issues. Millions of Christians, for example, come to obtain blessings from an image of the Black Madonna hidden among the rock spires of Montserrat, within Montserrat Natural Park in Catalonia, Spain (Mallarach and Papayannis 2007). Buddhist and Daoist pilgrims climb Taishan, the most important sacred mountain in China, to worship at various shrines and, in the case of elderly women, to pray for grandchildren (Bernbaum 1997). Not all of these pilgrims will have concerns about their potential impacts on local cultures and the environment.

Monasticism is another distinguishing feature of mainstream religions. Religious traditions, from Christianity to Buddhism, have chosen places with sacred significance in remote natural settings such as forests, deserts and mountains in which to establish monasteries where monks and nuns can practise contemplation in solitude far away from the distractions of civilisation. In Japan, for example, most Zen monasteries are named 'mountains' in recognition of the fact that East Asian cultures have long regarded mountains as ideal places in which to meditate and attain enlightenment (Bernbaum 2007). Recognising the importance of protecting natural settings conducive to spiritual development, monasteries in places such as the peninsula of Mount Athos in Greece have traditionally managed the lands around them in ways that have preserved biodiversity otherwise lost in surrounding areas.

Many natural sites are revered because a well-known hermit, such as the Biblical prophet Elijah in Judaism and Christianity or the yogi Milarepa in Tibetan Buddhism, has lived and practised there, imbuing the site with an aura of sanctity. Followers of mainstream religions come to these sites to receive the blessings they believe were left behind by the spiritual power of such hermits. Monasteries of mainstream religions often have close connections to places of hermitage, having grown up around a place where a hermit enshrined in their tradition lived and meditated, attracting followers who eventually developed a monastic community. Since natural settings have often played important roles in the lives and practices of hermits-witness, for example, the importance of animals, plants, and other features of nature for Saint Francis of Assisi-there is a natural inclination to protect the environment associated with these places. Managers can draw on these natural inclinations to strengthen the measures they implement in conjunction with interested parties from mainstream religions (Papayannis and Mallarach 2009).

Sacred natural sites in mainstream religions have associated with them myths and beliefs shared by large numbers of people. Hundreds of millions of Hindus, Buddhists and Jains revere Mount Kailas in Tibet as the centre of the universe and the abode of major deities and enlightened beings in their respective traditions. The biblical story of Moses's encounter with God on Mount Sinai and the revelation and covenant believed to have taken place there have had a profound influence not only on Judaism, Christianity and Islam, but also on the course of Western civilisation.

According to myth, the Korean people as a wholeboth North and South-are descended from Paekdu or Changbai Shan, a volcano on the North Korean border with Manchuria (Price et al. 2013). Monotheistic religions of Judaism, Christianity and Islam revere sacred natural sites not as deities but rather as places of worship, like churches and synagogues, or as places of God's divine creation worthy of love and respect. Such beliefs, both monotheistic and non-monotheistic, have a powerful influence that can be enlisted in motivating millions of people to support protected areas in particular and environmental conservation in general.

The following points are offered as guidance for protected area managers working with mainstream religions.

1. Managers of protected areas need to work with religious authorities and pilgrimage associations to manage the flow of pilgrims, provide facilities and services for them, and educate them about the need to protect the natural environment and respect the local culture. The situation is generally quite complex, potentially involving many parties.

2. Managers of protected areas that include monasteries can work with the leaders of monastic communities to include them in their management plans and integrate their practices into their management systems (Papayannis and Mallarach 2009). Abbots of Tibetan Buddhist monasteries in Sagarmatha National Park in Nepal, for example, control sacred groves around their monasteries and have the power to designate 'lama forests' as places that local Sherpa communities have powerful motivations to respect, even more than areas officially protected by the park itself (Mallarach 2008).

3. Because they draw large numbers of pilgrims and are places of monastic communities, many sacred natural sites in mainstream religion have extensive 
human-made structures associated with them. A major pilgrimage shrine such as Badrinath in the Indian Himalaya needs to provide facilities and temples for housing and serving the religious needs of the 400000 pilgrims who visit the site each summer. Large monasteries with churches and living quarters for monks are perched on crags and hidden in forests in protected areas in various parts of Europe-in particular, the Balkans, as well as in the Cedars of Lebanon in the Middle East.

4. Managers need to pay particular attention to the challenges associated with maintaining humanmade structures and the traditions connected with them while at the same time preserving the natural environment that surrounds and gives them their special significance. This requires working closely with religious leaders and monastic authorities, in addition to local communities. An additional point to consider is that many monasteries in Europe and Asia have extensive landholdings that include large tracts of relatively unspoiled nature that may already be associated with existing protected areas or be candidates to become new areas of protection (Papayannis and Mallarach 2009).

5. Sacred natural sites for mainstream religions may be much larger than sites for indigenous traditions and local communities, although the ancestral 'Dreaming' tracks of the creation beings can link natural features across vast distances in the cosmology of Aboriginal Australians. Hindus in India, for example, regard the length of the Ganges River and the entire Himalayan mountain range as sacred. Such large natural features and landscapes may cross multiple protected areas, the management plans and systems of which could be strengthened by integrating the cultural and spiritual values that link them together, not only for the people who live near them, but also for the more distant followers of the religions that revere them. In a sense, they form cultural corridors similar in certain respects to wildlife corridors.

6. Some natural sites are sacred to more than one mainstream religion or may also be sacred to indigenous traditions. Lake Manasarovar, a Ramsar site in Tibet, is regarded as the most sacred lake in the world for Hindus and also for many Tibetan Buddhists - and it has special significance for the indigenous Bon tradition of Tibet. Adam's Peak in the Peak Wilderness Area of Sri Lanka is a major place of pilgrimage for Hindus, Buddhists, Christians and Muslims - all of whom need to be taken into account in managing the area (Bernbaum
1997). Natural sites that are sacred to more than one religious or indigenous tradition pose the challenge of addressing conflicts that can arise among these traditions. Managers may have to deal with the question of which tradition, if any, has primacy over a particular site, although that is best left to the parties themselves to work out (see discussion earlier in this chapter).

7. Many indigenous traditions today fear the encroachment of mainstream religions on their sacred sites - a fear that managers need to deal with in making sure that all stakeholders' views and interests are represented in management plans and systems. In addition, there are also conflicts among different indigenous traditions and local communities laying claim to the same site-for example, disputes among the Hopi and Navajo over sacred places in the American south-west, many of them in protected areas.

8. Custodians of sites in mainstream religions usually come from distant places and are assigned by leaders of religious institutions headquartered elsewhere. The head of Saint Catherine's Monastery in charge of Mount Sinai or Jebel Musa, for example, comes from Greece and receives his appointment from the hierarchy of the Eastern Orthodox Church (Mallarach 2008). An illustration of the monastic influence in the effectiveness of conservation is presented in Case Study 22.7.

9. Sites sacred to multiple religious and indigenous traditions can have a number of custodians who may be at cross-purposes, and managers need to recognise the diverse nature and interests of custodians. In Christianity the notion of stewardship is emphasised, rather than custodianship per se, shifting the focus away from ownership and control to obligation and responsibility. Hindus may consider the real custodian of a sacred site to be the deity who dwells there and has power over the place, such as the goddess Nanda Devi in the Nanda Devi Biosphere Reserve. For some sacred sites, there may be no person or persons singled out as custodians (or knowledge may have been fragmented or lost due to colonisation). Instead various stakeholders and religious and pilgrimage organisations may be responsible for taking care of the site-and in some cases there may be no-one charged with protecting the place.

10. Sacred sites that draw many pilgrims and other visitors offer the opportunity to disseminate religiously based ideas of conservation for a particular site, and the environment. Sacred natural 


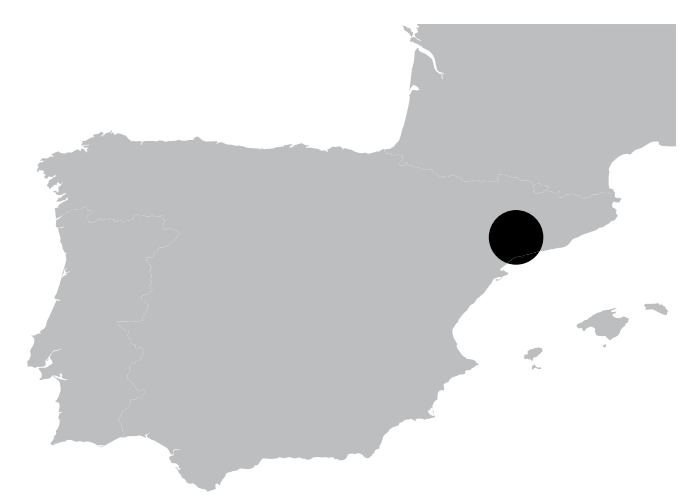

Figure 22.4 Indicative location on the Iberian Peninsula, Montserrat, Catalonia, Spain

Source: US NPS

Montserrat is located about 50 kilometres north of Barcelona. Despite its modest altitude (1120 metres) and relatively small size, the singular landform characterised by thousands of astonishing stony pinnacles makes it a unique, magical and majestic mountain. Montserrat includes outstanding geological heritage sites of national importance, more than 1200 Mediterranean vascular plant species, of which 40 are considered rare or endangered, and 29 animal species considered rare, endangered or vulnerable.

Nested into the mountain, over the cliffs, is the famous Benedictine monastery of Santa Maria, where the black image of the Holy Virgin is venerated. For many centuries, the shrine of the patroness of Catalonia-a masterpiece of sacred art from the 12th century-has been one of the most significant shrines of the Virgin in the Catholic world. In addition, the upper part of Montserrat has 12 hermitages, most of them clinging to rocky pinnacles, where hermits have been living for most of the past millennia. Two hermitages are still used by the monastic community for retreats, while two more are used as shelters for climbers. In 1954, on a ridge at a lower elevation, the monastery for nuns of Sant Benet was built. The tradition of pilgrimage by foot to venerate the holy image of the Virgin dates from medieval times. Today, although the majority of people use mechanical means, groups of pilgrims still climb by foot, following historical pilgrimage trails.

For all these and many other historical, political and sociological reasons, Montserrat is widely considered the identity and spiritual heart of Catalonia. In 1989 Montserrat was declared a Natural Park (IUCN Category V) with a Nature Reserve (IUCN Category III) by a decree of the Government of Catalonia. The protected area is about 9400 hectares, of which almost 2000 hectares is nature reserve. The entire massif has been included in the European Natura 2000 network. The Board of Montserrat is led by the President of Catalonia and the abbot of the monastery of Santa Maria.

The Benedictine community has been the main custodian of Montserrat for almost 10 centuries. The cultural influence and importance of the monastic community can be gauged from the following facts.

1. During the past four centuries it has had a significant school of liturgical music.

2. It has one of the oldest publishing houses in Europe.

3. Its library has more than 300000 volumes, including unique manuscripts.

4. The museum holds one of the best collections of landscape paintings of Catalonia.

5. The cultural work of the monks includes biblical studies, liturgy, theology, monastic history, musicology, as well as spiritual and pastoral themes, authoring or translating numerous works annually.

6. The monks organise numerous cultural activities.

In addition, the areas surrounding the Monastery of Santa Maria are an open air museum, including a number of sculptural groups of the 19th century that blend with the rocky walls along the trails.

- Josep-Maria Mallarach, Silene Association sites in protected areas can focus attention on and highlight in concrete ways such messages from major figures of mainstream religions on the pressing need to respect and care for nature. For instance, a project that had religious leaders and scientists working together to re-establish a sacred forest at Badrinath, a holy town in India, instituted treeplanting ceremonies that attracted a lot of attention and spread the idea of planting and taking care of trees elsewhere in India for reasons coming out of traditional Hindu beliefs and practices (Pungetti et al. 2012). The late Pope John Paul II and Patriarch Bartholomew I of Constantinople have used their religious authority to encourage the followers of their traditions to respect and care for the natural environment (Dudley et al. 2005).

\section{Managing tourists at sacred sites}

Many known sacred sites are major tourist attractions for the secular public, both national and international, because of their natural beauty and cultural interest. Large numbers of tourists come to see them, with potentially adverse impacts on the natural and cultural values of these sites. At the same time, these visitors bring revenue that can help support protected areas and local communities. In addition, major sacred natural sites, such as Mount Sinai and Mount Fuji, are well known to the majority of the public who do not have the opportunity to visit them but would like to know that they are being preserved for posterity. 


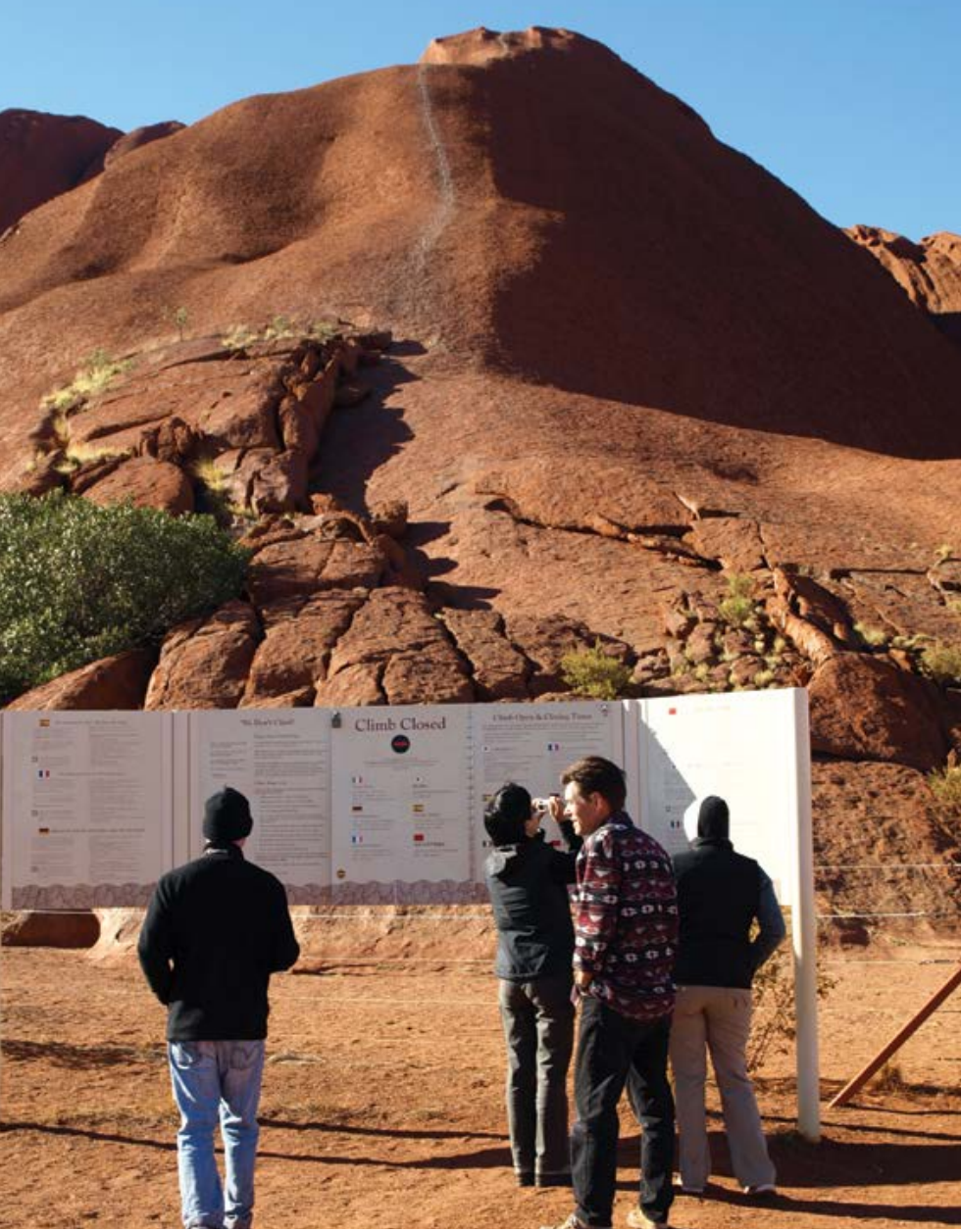

Sign provided at the base of the climb up Uluru, Uluru-Kata Tjuta National Park, Northern Territory, Australia

Source: Graeme L. Worboys

\section{Managing recreational use}

Recreational uses, in particular, such as rock climbing and skiing, can threaten the sanctity of sacred sites in the eyes of those who revere them. The Lakota and other tribes in Wyoming, for example, regard the ascent of Devil's Tower (or Mato Tipila) in Devil's Tower National Monument as an act of desecration, especially during their ceremonial season in June. The park managers tried to ban climbing during this period, but a small group of climbers contested this in court and won, saying it violated their rights. The management now asks people to voluntarily refrain from climbing the volcanic tower in June out of respect for Native American traditions, and the overwhelming majority of climbers have agreed to do so (Wild and McLeod 2008).

Expansion of the Arizona Ski Bowl and the use of waste water to create artificial snow on the sacred San Francisco Peaks have pitted tribes such as the Hopi and Navajo against the ski area and members of the skiing public. The Native Americans have gained the support of environmental organisations such as the Sierra Club, but up to this point, have not succeeded in court in stopping the use of waste water and other aspects of recreational skiing they regard as desecrations of the sacred mountain (Papayannis and Mallarach 2009).

\section{'We Don't Climb'}

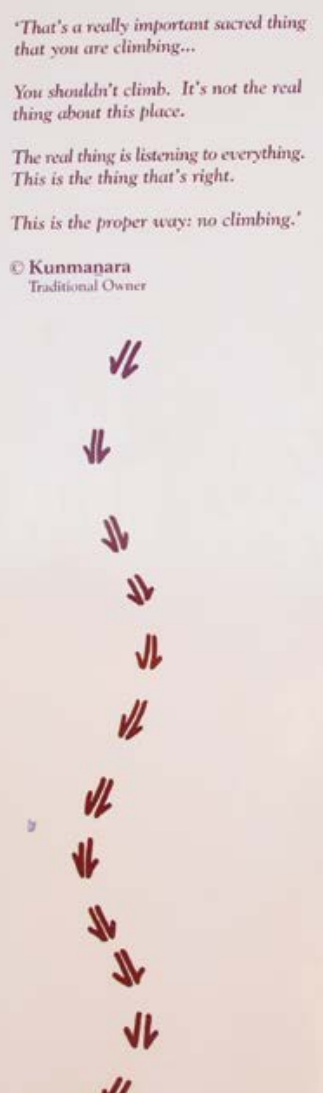

\section{Please Don't Climb Uluru}

Our traditional Law teaches us the proper way to behave. We ask you to respect our Law by not climbing Uluru.

What visitors call 'the climb' is the traditional route taken by ancestra Mala men upon their arrival at Uluru in the creation time. It has great spiritual significance.

We have a responsibility to teach and safeguard visitors to our land. 'The climb' is dangerous and too many people have died while attempting to climb Uluru. Many others have been injured while climbing. We feel great sadness when a person dies or is hurt on our land. We worry about you and we worry about your family.

Other things to do

$$
\begin{aligned}
& \text { There are other challenging and interesting things to do at the Uluru } \\
& \text {-Kata Tjuta National Park. } \\
& \text { - Walk around the base of Uluru (9.4 kilometres) } \\
& \text { - Challenge yourself to the Valley of the Winds Walk } \\
& \text { - Appreciate our culture while visiting the Cultural Centre } \\
& \text { - Join a free Ranger-guided Mala Walk } \\
& \text { - Go on a self guided Mala Walk ( } 2 \text { kilometres) and Mutitjulu } \\
& \text { walk (1 kilometre). Purchase the Insight Into Ulunu brochure to } \\
& \text { - Telp guide you } \\
& \text { - Visit Kata Tjuta for sunrise, sunset, day walks or a picnic } \\
& \text { - Look for animal tracks on a dune walk at the bus sunset area } \\
& \text { - Sit and listen to the wind, the trees, the birds and animals } \\
& \text { - Watch sunrise and sunset at Uluru } \\
& \text { - Picnic at the grounds near the Cultural Centre. } \\
& \text { When you visit the Cultural Centre you will learn more about the } \\
& \text { significance of Uluru in our Law and culture. Please do this before } \\
& \text { you decide whether to climb. } \\
& \text { If you look to your left you will see the start of the Mala Walk. } \\
& \text { Mala Trucks Artuonk Jemnifer Taylor }
\end{aligned}
$$

Detail of the sign provided at the base of the climb up Uluru, Uluru-Kata Tjuta National Park, Northern Territory, Australia

Source: Graeme L. Worboys

Another important example of the management of sacred natural sites comes from the Dai people living in the convergence of north-west Vietnam, eastern Myanmar, upper Laos, northern Thailand and the Yunnan region of south-west China. Before the introduction of Hinayana Buddhism with the Tang Dynasty, the Dai were animistic, linking the forces of nature with the spiritual realm through the idea of $S h u$, the mountain spirit. The Dai have maintained and increased the biodiversity potential and abundance of native flora and fauna on the sacred hills (or Nongs) by maintaining rituals to control the evil spirit of Shu, associated with the use of timber and other resources, such as medicine or food, only by community and religious consent. Harvesting timber from species such as Paramichelia baillonii, Cinnamomum comphora, C. glanduliferum and Gmelina arborea requires the consent of a village committee, which has retained forested hills in the otherwise transformed farmscape of rice paddies, home gardens and cultivated fields, thus satisfying the benevolent spirit of Shu. The Dai's respected souls of their chieftains reside in the forested hills of the local Nong Man or the larger Nong Meng, and reportedly help contribute to the preservation of local and regional landscapes (Xu et al. 2006). 


\section{Managing cultural features (tangible cultural heritage)}

Most protected areas have considerable tangible cultural heritage, but it is often of a fragmentary and subtle nature-archaeological rather than monumental. They do not typically consist of prominent buildings or wellknown rock art sites. The management of these more subtle and often more fragile heritage sites requires a range of sophisticated techniques, often in an environment of few resources. The protected area manager, as has been mentioned before in this chapter and in Chapter 4, is often someone without a background in cultural heritage management and may not recognise many of the cultural heritage values of a protected area without the aid of cultural heritage specialists and/or the local community. Locating, identifying, inventorying and assessing these sites and landscapes are prerequisites to formulating management strategies. Methodologies for management need to begin with a discussion of these issues and suggested strategies for their achievement. After this, often the best strategy is to write a management plan for the conservation of the cultural heritage generally rather than initially focusing on specific sites.

It is important to note here that we are not suggesting that tangible evidence, such as the built environment, is separate from the surrounding landscape; they are all part of an integrated holistic system involving nature and culture evolving together (biocultural diversity). Managing and protecting tangible evidence, however, commonly require specific technical expertise and management practices, and our discussion is focused on these special requirements.

The most important international policy document for conserving tangible cultural heritage-specifically built heritage-is the International Charter for the Conservation and Restoration of Monuments and Sites, known as the Charter of Venice, which resulted from the deliberations of practitioners about restoration of flooddamaged buildings in Venice in 1964 and which gave rise to the International Council on Monuments and Sites (ICOMOS) (Lennon 2006). Other global agencies connected with ICOMOS in the management and protection of cultural heritage include UNESCO, the International Centre for the Study of the Preservation and Restoration of Cultural Property, the International Council of Museums (ICOM), the World Heritage Convention and the IUCN. Various nations have adapted the guiding principles of ICOMOS to suit their particular circumstances, such as Australia's Burra Charter, established in 1979, the China Principles (2004), A Preservation Charter for the Historic Towns and areas of the United States of America (US/ ICOMOS 1992), and the Charter for the Preservation of Quebec's Heritage (ICOMOS Canada) (Lennon 2006). UNESCO's Hoi An Protocols (UNESCO 2009) provide professional guidelines for preserving the authenticity of heritage sites in the context of the diverse and enduring cultural identities of Asia. Despite these universal guidelines, best management practice varies from continent to continent, even from country to country, for a range of reasons, including the funds available to manage historic buildings and landscapes and the levels of visitation.

Historic buildings occur in protected areas across the world; sometimes they can even be the reason for the protected area, or they can be incidental to the main reason-for example, graziers' and miners' huts in Kosciuszko National Park, Australia (see Chapter 4). The significance of a built feature is often not immediately apparent to anyone, let alone a protected area manager. For example, it may not be the fabric or physical evidence that is significant, but the historical events associated with the place. Generally, the way a built feature is managed depends on its values and the level of significance of the values. The process of assigning values then assessing significance marks the onset of the conservation planning process, which is discussed further below.

\section{The conservation planning process}

As discussed in Chapter 4, managing and conserving cultural features, including cultural landscapes and biocultural diversity, should ideally be guided by careful and rigorous conservation planning-often by heritage experts. This involves a values-based assessment process followed by a series of well-defined steps, right through to reporting and monitoring on the status of the identified values (Figure 22.5). These steps are often articulated through a conservation management plan, particularly where the feature is substantial or of great significance. Any such plan would need to be consistent with any other plans relevant to the protected area.

Thorough research using all available sources leads to an understanding of the place and enables an assessment of its values. Heritage values can reside in the form, materials, craftsmanship and setting of the place and also in the associations and memories that people have with a place. Heritage values differ from culture to culture and for different periods of social history. They are closely tied to authenticity in both the fabric and the associated documentary evidence. Lennon (2006) contains useful information regarding values, authenticity and significance. ICOMOS Australia identifies five values, shown in Table 22.1 (see also Chapter 4). 
Table 22.1 Cultural heritage values

\begin{tabular}{|l|l|}
\hline Cultural value type & Description \\
\hline Aesthetic value & $\begin{array}{l}\text { Sensory perception such as form, scale, colour, texture and material of the fabric or the } \\
\text { smells and sounds associated with the place and its use }\end{array}$ \\
\hline Historic value & $\begin{array}{l}\text { A place has influenced, or has been influenced by, a historic figure, event, phase or } \\
\text { activity; site of an important event }\end{array}$ \\
\hline Scientific/research value & $\begin{array}{l}\text { Importance of the data; rarity, representativeness, degree to which the place may } \\
\text { contribute further substantial information }\end{array}$ \\
\hline Social value & $\begin{array}{l}\text { Qualities for which a place has become a focus of spiritual, political, national or other } \\
\text { cultural sentiment to a majority or minority group }\end{array}$ \\
\hline Spiritual value & $\begin{array}{l}\text { Used to capture the attachment between humans and the natural environment/place, } \\
\text { being more specific than social or aesthetic }\end{array}$ \\
\hline
\end{tabular}

Source: Australia ICOMOS (2013)

Once the values have been identified and there is a consensus among stakeholders (not always easy to achieve), an assessment of cultural significance demonstrates the degree to which the heritage features possess the defined values. A clear and concise statement of cultural significance is prepared, which can be for an entire feature or there can be separate statements for separate elements making up a large and complex feature.

While stage one focuses on the place itself, stage two is concerned with policy development, weighing the obligations arising from the significance assessment with external factors that may influence future management of the place. For example, it would not be useful to have a policy of total restoration of a building if there is no available funding.

Stage two is likely to involve lengthy discussions between the heritage practitioner, park managers and stakeholders. Once policies have been developed, a management plan can be prepared that operationalises the policies into objectives and actions that are prioritised and funded. An effective monitoring and review process should be included in the management plan. A conservation management plan should be clear on what is and what is not acceptable for the heritage feature, such as whether a building can be moved; whether movable heritage can be removed to a museum; the amount of new fabric that can be introduced; the appropriate type of furniture to use; and the amount of funding to be allocated to maintaining an old or derelict building. The following factors may be important to consider when developing a conservation management plan.

- Visitor use: The sustainability of visitor levels needs to be assessed to determine whether they are compatible with the retention of the cultural significance of the protected area.
- Interpretation: Methods for revealing the significant values of the place to the public should be outlined, if there is to be public use. This may involve treatment of the fabric to show historic meanings, the use of the place in a way consistent with its original use, the use of introduced interpretative material or use of local people as guides.

- Constraints on investigation: There may be cultural, social, ethical or religious reasons that prevent or limit investigation of the cultural landscape or access to historic sites by researchers, workers or the public.

- Future developments likely to occur: The conservation plan must examine possible future developments and their impact on the heritage values. Developments of any scale should also be assessed through environmental impact assessment procedures and appropriate mitigation strategies.

The aim is for a workable conservation plan that can be adapted to changing conditions while retaining the significance of the heritage values expressed in the place.

The management plan may incorporate conditions for alternative scenarios, allowing the manager to respond to changes in use or physical condition of the place. The treatment actions can range from cyclical maintenance and restoration to continuing traditional ways of living or adaptive reuse. The appropriateness of particular treatments should be carefully evaluated before any works commence. The appropriateness of treatments will also vary depending on the type of protected area and scale of impact. For example, in designed landscapes there may be reconstruction of missing elements, as at the World Heritage-listed Lednice-Valtice Cultural Landscape in the Czech Republic, one of the largest artificial landscapes in Europe; rehabilitation and restoration following damage at Hampton Court Palace gardens in the United Kingdom; and reconstruction 
via the replanting of 50000 trees at Versailles following severe storms in 1999, which devastated the formal French gardens dating back to Louis XIV.

The management principles for places listed on Australia's National Heritage register are also useful.

- The objectives in managing heritage landscapes are to identify, protect, conserve, present and transmit, to all generations, their heritage values.

- Management of heritage places should use the best available knowledge, skills and standards for those places, and include ongoing technical and community input to decisions and actions that may have a significant impact on their heritage values.

- Management of heritage landscapes should respect all values of the place.

- Management of heritage places should ensure that their use, presentation and interpretation to visitors are consistent with the conservation of their heritage values.

- Management of heritage sites should make timely and appropriate provision for community involvement, especially by people who have a particular interest in, or association with, the place, and may be affected by the management of the place.

- Indigenous people are the primary source of information on the value of their heritage and their active participation in identification, assessment and management is integral to the effective protection of indigenous heritage values.

- Management of heritage landscapes should provide for regular monitoring, review and reporting on the conservation of heritage values of the sites (Department of the Environment 2014).

Cultural associations must be maintained to keep the associative values alive as detailed in the significance assessment conducted as part of the conservation planning process. This requires cooperation and collaboration between community group leaders and knowledge-holders and protected areas managers. It may include education programs, seasonal activities, intergenerational meetings and festivals to transmit rituals and crafts, language and pride in local costume. Values can be dynamic, however: they evolve and change. Evaluation of condition and knowledge about these values must be updated, and therefore management strategies must be able to change to protect the protected areas' expressed values.

The popular ranger-guided Mala Walk at the base of Uluru and towards Kantju Gorge, Uluru-Kata Tjuta National Park, Northern Territory, Australia. This walk features spectacular overhangs and caves, Aboriginal paintings and sites of special significance to the Aboriginal community.

Protection of these features is provided by the design of elevated viewing platforms and the route of the track.

Source: Graeme L. Worboys

\section{Managing visitors at historic sites}

Many historic buildings are opened to the public, sometimes to raise funds to assist in their upkeep. The conservation plan for historic buildings should identify the type of circulation of visitors and their frequency along specific hallways, corridors or staircases. For instance, when visiting the Royal Palace in London, visitors can direct their attention to landmark statues or prime murals as indicators of the type of collections that will be on display. When visiting sensitive historic buildings, observance of silent reading or the use of audiovisual self-guided tours may be requested, with restricted visiting hours. When visiting historic temples in Kyoto, Japan, visitors may access certain rooms of the main floor only if they have removed their shoes or have the disposable shoe-covers provided by management. Historic buildings that display bibliographic collections provide authorised visitors with nose and mouth filters and cotton gloves. 
Other impacts on historic buildings and monuments can include soot and dust accumulation on exposed surfaces, and visual and sound contamination in urban areas. Heritage sites should have a buffer space-for example, a garden. That buffer could ameliorate these problems and provide a curtilage to the site.

High numbers of visitors can impact on built heritage, which can be ameliorated in several ways. Numbers can be limited to a maximum at any one time, or the building areas open to the public could be restricted, or the site could be closed at certain times of the year. Public support may diminish, however, unless there are good educational programs to explain why such measures are necessary. Revenue may also decline, which could have negative consequences for the management authority and local communities.

Alternatively, sites can be 'hardened'. At Throsby Park Historic Site, a grand Georgian sandstone homestead in New South Wales, Australia, fragile carpets were covered with thick plastic to enable visitors to walk through the building without causing damage. Elevated walkways can be built around archaeological sites such as at the World Heritage-listed 8000-year-old Çatal Hüyük in Turkey (see Chapter 4), or in rock shelters containing galleries of ancient paintings. Monitoring the impacts of visitors is crucial for ensuring that services are not overloaded and significant fabric is not damaged, and to identify when works are needed to retain the significance of the place.

Where appropriate, multilingual signage should be displayed. Brochures should be made available for site visitors, providing they will not cause a litter problem. A resource centre could also be developed at the site, where visitors could have access to relevant information about the site's history and cultural significance. Links to social media sites should be clearly exhibited for those who want to link with other people and blog about their experiences.

Most importantly, architects, archaeologists, rangers, communicators, ecologists, sociologists and other professionals involved in heritage sites should be given site instruction and training that introduces them to the philosophy and techniques of conservation, restoration and site operation as they apply to the specific location.

In some instances, tourists can experience cultural heritage without directly seeing it. For example, artwork on cave walls may be too fragile to be subjected to tourists and their carbon dioxide-rich breath. Visitors cannot enter such caves; instead, they receive their visual instruction at interpretation centres designed to

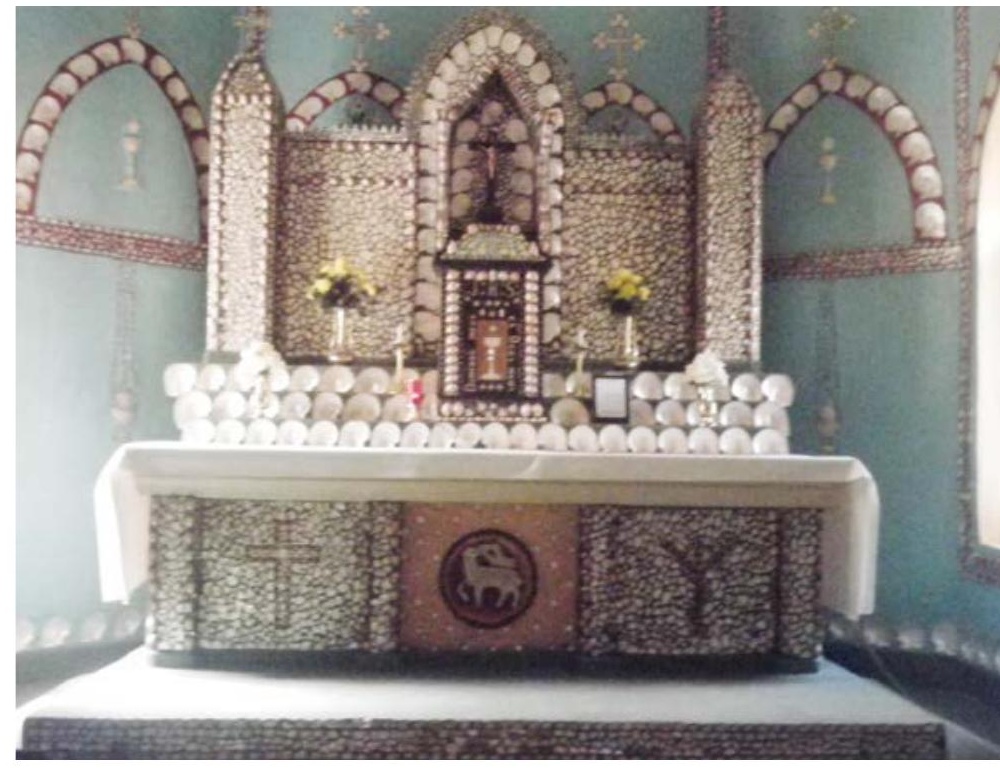

Mother-of-pearl inlaid alter, Sacred Heart Church, old Beagle Bay Aboriginal Mission, Dampier Peninsula, Northern Territory, Australia. The church was built in 1890 by French Trappist monks and attracts revenue for the local Aboriginal community from donations.

Source: Sue Feary

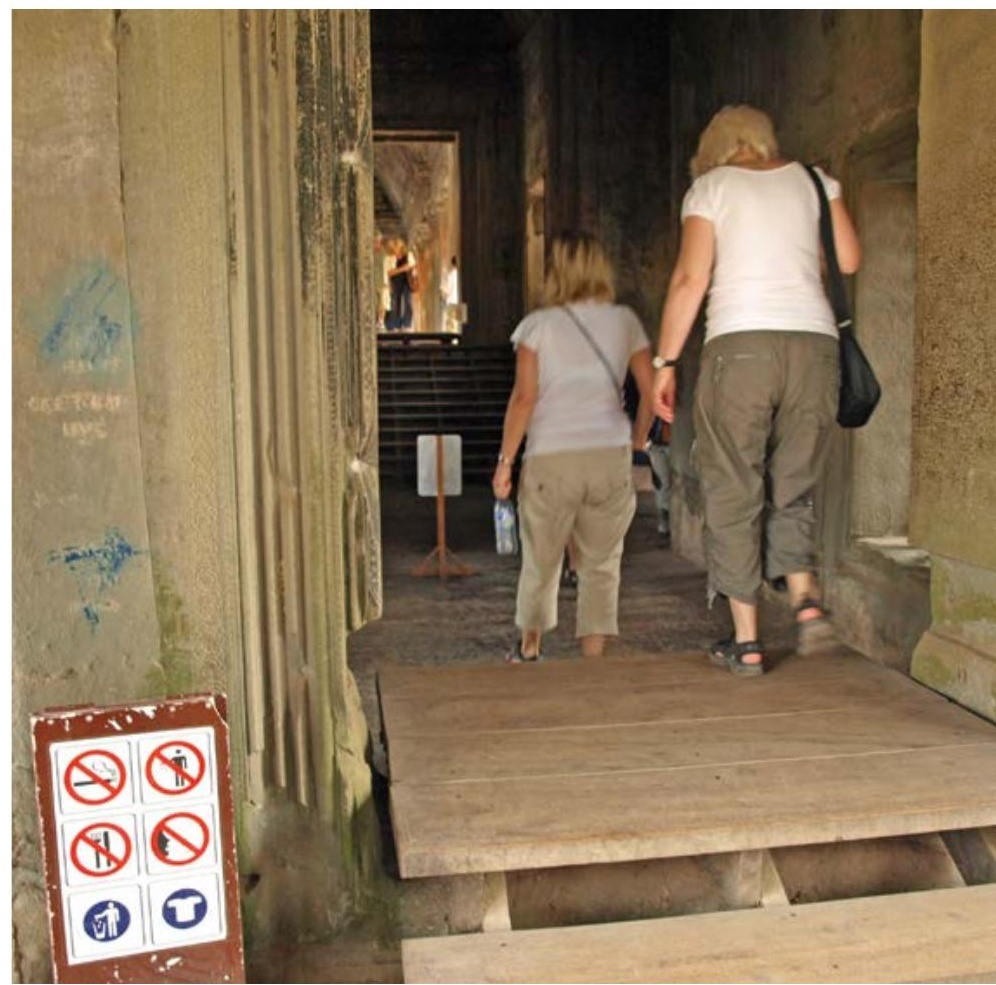

International regulatory signs at Angkor Wat, Cambodia, used to help protect the site from pollution (food scraps, cigarette butts and garbage), noise pollution and to achieve culturally acceptable dress. The wooden steps help to protect the stone doorway from heavy foot traffic. Source: Graeme L. Worboys 
accommodate a great number of people arriving at the premises, such as in the Altamira Caves near Antillana del Mar, Cantabria, in northern Spain.

If access to the site is needed, special paths can be marked with strict direction of circulation and clear signs that make the experience self-explanatory. Where possible, interpretation pathways with illustrative signage allowing disabled access are desirable. Notices about not using flash photography or other invasive observation practices may also be appropriate.

\section{Managing heritage features in a changing world}

Important heritage sites can be affected by many events, both natural and humanly determined. For example, climate change processes such as the melting of glaciers may threaten shrines in mountainous areas. An example of an extreme case of human intervention is removal of the Great Temple complex of Abu Simbel to allow construction of the Aswan Dam in Egypt. The structure was completely rebuilt at another location using the same materials and design of the original structure. The original feature was cut into blocks and the pieces reassembled in their new location (Fitzgerald 2008).

On the positive side, ancient structures that have been flooded due to natural or socio-political reasons can serve as in situ subaquatic displays that tourists can dive to see (see Chapter 4 on underwater heritage). Diving around submerged structures is a relatively new form of tourism becoming popular in the sunken villages of Ngibtal and Babeldaob in Palau, Micronesia, the Yucatán Peninsula in the Caribbean and in some shipwrecks of the Mediterranean Roman trade route. The sustainability of this activity has yet to be determined, as looting is an ever-present danger (Guérin et al. 2010).

\section{Managing research at archaeological sites}

While most nations and their teaching institutions have well-established principles and policies to guide research at heritage sites, each site has its own unique circumstances with which practitioners must become familiar. For example, when an archaeological dig in a protected area is needed to obtain data relevant to understanding or managing the site, best archaeological practice must prevail, not only in relation to excavation methodologies, but also to ensure safe removal and deposition of excavated sediment, maintaining the landscape integrity of the protected area or cultural goods and, where relevant, the tranquillity and soft pace of the lifestyle of the communities in the region.

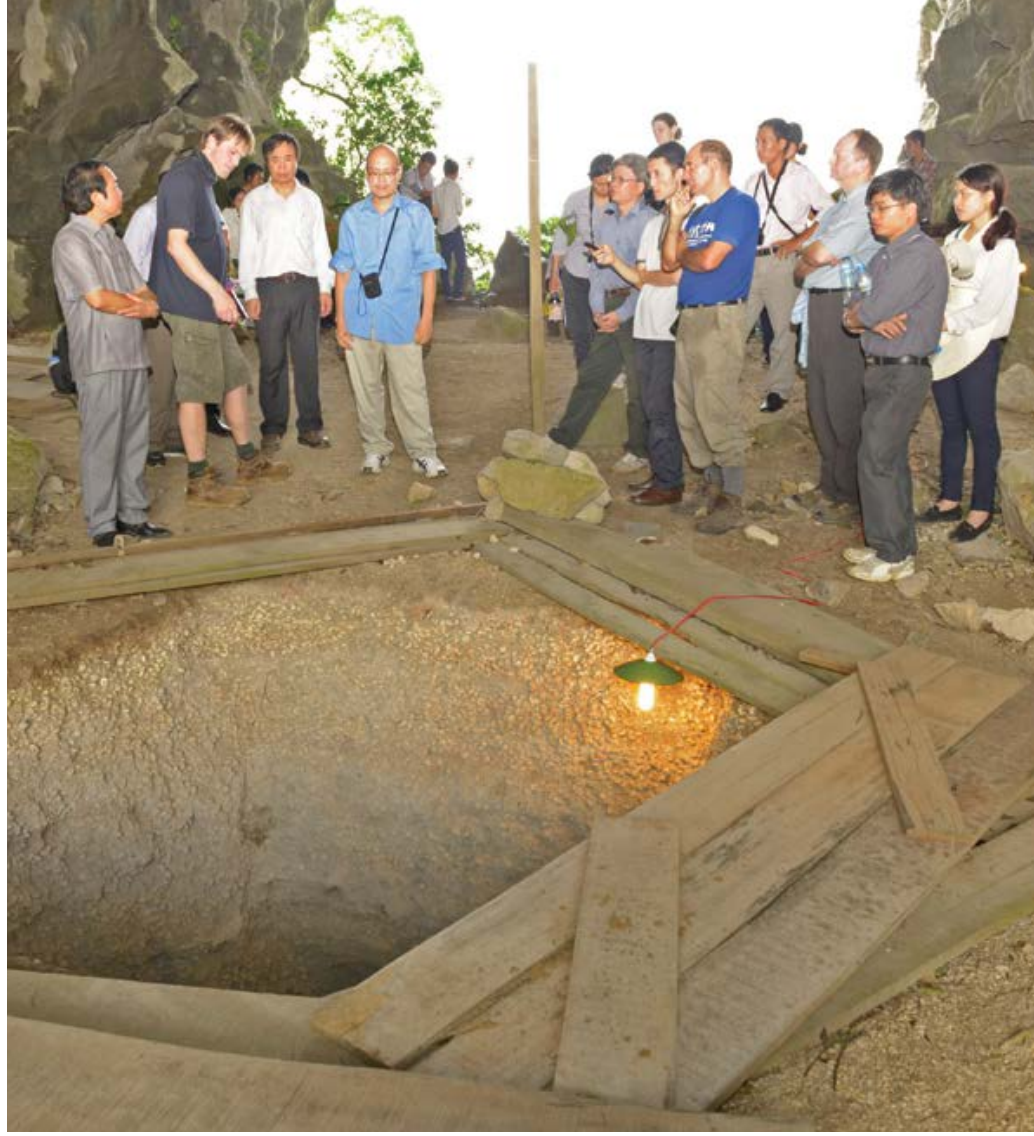

Archaeologists briefing visiting experts to Hang Trong Cave, Trang An Landscape Complex World Heritage Property, Vietnam, about the excavation of a human occupation deposit that dates back 24438 years. Visitor use restrictions to this area help protect the excavation site.

Source: Graeme L. Worboys

Generally, heavy excavation machinery is not permitted in archaeological excavations within a protected area, although this will be guided by relevant management plans and conservation strategies. Where possible, local community members should be employed to assist with archaeological research. This not only provides local employment; it also enables people to connect with their heritage through direct participation in research and management, such as with the Eastern Band of the Cherokee in the operation of the museum and community centre in North Carolina. Involvement of Aboriginal Australians in archaeological research is a requirement of State and national regulatory authorities and of ethics committees of most universities in Australia.

\section{Managing and conserving records}

While protected area managers in the Western world have been working with computer technology for many decades, there are countries where computer hardware and software are not readily available. Ideally, files, records, archival materials including maps, designs and photographs should be digitised and safeguarded within the electronic system, including at least three backups kept at different locations. The International Committee for Documentation of Cultural Heritage (CIPA), one of the technical branches of ICOMOS, advises on the 
acquisition of data and information for the purpose of documenting cultural heritage, and manages the information, and provides education and training at different levels. Good record-keeping of historical records, which are heritage in themselves, is a critical element of cultural heritage management. UNESCO has established guidelines to handle historically relevant records (CIPA 2007).

There are many countries where computing, archival and cataloguing facilities and services are limited, nonexistent or in their infancy. An example is the Solomon Islands, whose archives, located in the nation's capital, Honiara, hold many written records including those of British colonial settlement, and the history of activities of churches and missionaries over many decades. An unreliable electricity supply, natural disasters, lack of equipment and lack of training of local people put these valuable records at great risk. The Solomon Islands Government solved the problem by using Australian foreign aid and a partnership with The Australian National University to digitise many of its records. It also called for volunteers under the Australian Volunteers Abroad scheme, to write manuals and train staff in the management of records. Funds were also found to buy a generator to combat the inevitable daily electricity outages.

\section{Conclusion}

In this chapter, we have seen how protected area philosophies have responded and changed to accommodate new concepts such as cultural landscapes and biocultural heritage. These concepts recognise past and ongoing human use of protected area environments as well as showing us a way forward in managing protected areas and their precious natural and cultural values. In many parts of the world, an effective way for maintaining the cultural heritage values of protected areas is through their continued use by people for spiritual and cultural practices or for livelihood reasons. This continual use keeps the heritage value highlighted and in some instances could mean the best protection for both cultural and natural values.

This chapter has championed the importance of taking an integrated approach to managing culture and nature and has provided guidance on how to achieve this by way of case studies and examples. We have considered the importance of the conservation planning process in managing cultural heritage, and how values underpin assessment of cultural significance, which then forms a basis for policies and objectives in a rational and transparent way.

Management of some aspects of tangible cultural heritage has been explored, particularly the opening up of heritage buildings and religious sacred sites for mass tourism. A large proportion of the chapter has been devoted to discussion of managing sacred sites, both natural and built, of mainstream religions. Many such sites have recognised universal value and are well known and receive very high levels of visitation by pilgrims and tourists, requiring active management as a result.

\section{References}

\section{Recommended reading}

Amend, T., Brown, J., Kothari, A., Phillips, A. and Stolton, S. (eds) (2008) Protected Landscapes and Agro-Biodiversity Values, Values of Protected Landscapes and Seascapes Series Vol. 1, IUCN and GTZ, Kasparek-Verlag, Heidelberg.

Apgar, J., Ataria, J. and Allen, W. (2011) 'Managing beyond designations: supporting endogenous processes for nurturing biocultural development', International Journal of Heritage Studies 17(6): 555-70.

Argumedo, A. (2008) 'The Potato Park, Peru: conserving agrobiodiversity in an Andean indigenous biocultural heritage area', in T. Amend, J. Brown, A. Kothari, A. Phillips and S. Stolton (eds) Protected Landscapes and Agrobiodiversity Values, pp. 45-58, Protected Landscapes and Seascapes Series Vol. 1, IUCN and GTZ, KasparekVerlag, Heidelberg.

Australia International Council on Monuments and Sites (Australia ICOMOS) (2013) The Burra Charter: The Australia ICOMOS charter for places of cultural significance, Australia ICOMOS Secretariat, Melbourne.

Berkes, F. and Folke, C. (1998) Linking Social and Ecological Systems: Management practices and social mechanisms for building resistance, Cambridge University Press, Cambridge.

Bernbaum, E. (1997) Sacred Mountains of the World, University of California Press, Berkeley. 
Bernbaum, E. (2006) 'Sacred mountains: themes and teachings', Mountain Research and Development 26: 304-9.

Bernbaum, E. (2007) 'Great Smoky Mountains (shagonage) and Qualla boundary: Tennessee and North Carolina, southern Appalachian Mountains, United States of America', in J.-M. Mallarach and T. Papayannis (eds) Nature and Spirituality in Protected Areas: Proceedings of the first workshop of the Delos Initiative, pp. 201-18, IUCN and Publicacions de l'Abadia de Montserrat, Gland and Barcelona.

Blattel, A., Gagnon, G., Côté, J. and Brown, J. (2008) 'Conserving agro-biodiversity on the Gaspé Peninsula of Québec, Canada. A potential role for paysage humanisé designation', in T. Amend, J. Brown, A. Kothari, A. Phillips and S. Stolton (eds) Protected Landscapes and Agrobiodiversity Values, pp. 96-104, Protected Landscapes and Seascapes Series Vol. 1, IUCN and GTZ, Kasparek-Verlag, Heidelberg.

Borrini-Feyerabend, G. (2002) 'Interview on local communities and protected areas', Parks 12(2): 2-5.

1 Borrini-Feyerabend, G., Dudley, N., Jaeger, T., Lassen, B., Pathak, N., Phillips, A. and Sandwith, T. (2013) Governance of Protected Areas: From understanding to action, Best Practice Protected Area Guidelines Series No. 20, IUCN, Gland.

Brown, J. (in press [a]) 'Stewardship of protected landscapes by communities: diverse landscapes, diverse governance models', in K. Taylor, A. St Clair and N. Mitchell (eds) Cultural Landscapes: Preservation challenges in the 21st century, Routledge, New York.

Brown, J. (in press [b]) 'Bringing together nature and culture: integrating a landscape approach in protected areas policy and practice', in R. Gambino and A. Peano (eds) Nature Policies and Landscape Policies: Towards an alliance, European Documentation Centre on Nature Park Planning and Springer Verlag, Torino.

Brown, J. and Hay-Edie, T. (2013) COMPACT: Engaging communities in the stewardship of world heritage, UNDP, New York.

Brown, J. and Kothari, A. (2011) 'Traditional agricultural landscapes and community conserved areas: an overview', Management of Environmental Quality 22(2): 139-53.
Brown, J., Mitchell, B. and Beresford, M. (eds) (2005) The Protected Landscape Approach: Linking nature, culture and community, IUCN, Gland.

Cepek, M. (2012) A Future for Amazonia: Randall Borman and Cofán environmental politics, University of Texas Press, Austin.

Conservation Studies Institute (2005) A Handbook for Managers of Cultural Landscapes with Natural Resource Values, US National Park Service, Woodstock, VT. <www.nps.gov/csi>

Department of the Environment (2014) Managing National Heritage Places, Government of Australia, Canberra. <www.environment.gov.au/topics/ heritage/about-australias-heritage/national-heritage>

Dudley, N. (ed.) (2008) Guidelines for Applying Protected Area Management Categories, IUCN, Gland.

Dudley, N. and Stolton, S. (eds) (2012) Protected Landscapes and Wild Biodiversity, Values of Protected Landscapes and Seascapes Series Vol. 3, IUCN, Gland.

Dudley, N., Higgins-Zogib, L. and Mansourian, S. (2005) Beyond Belief: Linking faiths and protected areas to support biodiversity conservation, WWF, Equilibrium and the Alliance of Religions and Conservation (ARC), Manchester and Gland.

Environmental Information System of Colombia (SIAC) (2014) Indian Reservation. <www.siac. gov.co/Estado_Ecosistemas_Bosque/Resguardos_ indigenas 1. aspx>

Finke, G. (2012) Landscape Interfaces: World heritage cultural landscapes and IUCN protected areas, Thematic study published by the IUCN World Heritage Programme, IUCN, Gland.

Finke, G. (2013) Linking Landscapes: Exploring the relationships between World Heritage cultural landscapes and IUCN protected areas, IUCN, Gland.

Fitzgerald, S. (2008) Ramses II: Egyptian pharaoh, warrior and builder, Compass Point Books, New York.

Gilligan, B. (2006) The National Reserve System Programme Evaluation: Indigenous Protected Area programme, Australian Department of Environment and Heritage, Canberra. 
Guérin, U., Egger, B. and Penalva, V. (eds) (2010) Underwater Cultural Heritage in Oceania, The Society for International Cultural Exchange, UNESCO, Paris.

Dd Harmon, D. and Putney, A. D. (2003) Full Value of Parks: From the economics to the intangible, Rowman \& Littlefield, Lanham, MD.

Hay-Edie, T., Howard, P., Martin, G. and McCandless, S. (2011) 'The roles of local, national and international designations in conserving biocultural diversity on a landscape scale', International Journal of Heritage Studies 17(6): 527-36.

Infield, M. and Mugisha, M. (2013) Culture, Values and Conservation: A review of perspectives, policies and practices, Fauna and Flora International, Cambridge.

International Committee for Documentation of Cultural Heritage (CIPA) (2007) Recording, Documentation and Information Management for the Conservation of Heritage Places: Guiding principles, CIPA, ICOMOS and UNESCO, The Getty Conservation Institute, Los Angeles.

International Council on Monuments and Sites (ICOMOS) (1987) The Dresden Declaration on Colonial Buildings, UNESCO-ICOMOS, Paris.

Kothari, A., Camill, P. and Brown, J. (2013) 'Conservation as if people also mattered: policy and practice of community-based conservation', Conservation and Society 11(1): 1-15.

Lennon, J. (2006) 'Cultural heritage management', in M. Lockwood, G. L. Worboys and A. Kothari (eds) Managing Protected Areas: A global guide, pp. 448-73, Earthscan, London.

Lino, C. F. and Britto de Moraes, M. (2005) 'Protecting landscapes and seascapes: experience from coastal regions of Brazil', in N. Mitchell and M. Beresford (eds) The Protected Landscape Approach: Linking nature, culture and community, pp. 163-78, IUCN, Gland.

Loh, J. and Harmon, D. (2005) 'A global index of biocultural diversity', Ecological Indicators 5: 231-41.

Mallarach, J.-M. (ed.) (2008) Protected Landscapes and Cultural and Spiritual Values, IUCN, GTZ and Obra Social de Caixa Catalunya, Heidelberg.
Mallarach, J.-M. (ed.) (2012) Spiritual Values of Protected Areas of Europe: Workshop proceedings, BfN Bundesamt für Naturschutz, Bonn.

Mallarach, J.-M. and Papayannis, T. (eds) (2007) Protected Areas and Spirituality: The proceedings of the first workshop of the Delos Initiative, IUCN and Publicacions de l'Abadia de Montserrat, Gland and Barcelona.

Mallarach, J.-M., Comas, E. and de Armas, A. (2012) El patrimonio inmaterial: valores culturales y espirituales - manual para su incorporación en las áreas protegidas [Intangible Heritage: Cultural and spiritual values- $A$ handbook for inclusion in protected areas], Ed. Fundación Fernando González Bernáldez, Madrid.

Melnick, R. (1984) Cultural Landscapes: Rural historic districts in the national parks system, US National Park Service, Washington, DC.

Mitchell, N., Rössler, M. and Tricaud, P.M. (2009) World Heritage Cultural Landscapes: $A$ handbook for conservation and management, UNESCO World Heritage Centre, Paris.

Nash, R. (2001) Wilderness and the American mind, 4th edn, Yale University Press, New Haven, Conn.

National System of Protected Areas (SINAP) (2014) National System of Protected Areas (Sistema Nacional de Áreas Protegidas), Colombia. < runap. parquesnacionales.gov.co/index/contenido/seccion/ acercaderunap>

Papayannis, T. and Mallarach, J.-M. (eds) (2009) The Sacred Dimension of Protected Areas: Proceedings of the second workshop of the Delos Initiative, IUCN and Med-INA, Gland and Athens.

Parque de la Papa (2013) The Potato Park as an Indigenous Biocultural Heritage Area (IBCHA), Parque de la Papa, Peru. <www.parquedelapapa.org/ eng/03parke_01.html>

Phillips, A. (2003) 'Cultural landscapes: IUCN's changing vision of protected areas', in M. Rössler (ed.) Cultural Landscapes: The challenges of conservation, World Heritage Papers No. 7, UNESCO World Heritage Centre, Paris.

Posey, D. (ed.) (1999) Cultural and Spiritual Values of Biodiversity, UNEP, Nairobi. 
Price, M., Byers A., Friend, D., Kohler, T. and Price, L. (eds) (2013) Mountain Geography: Physical and human dimensions, University of California Press, Berkeley.

Pungettti, G., Oviedo, G. and Hooke, D. (eds) (2012) Sacred Species and Sites: Advances in biocultural conservation, Cambridge University Press, New York.

Rodwell, D. (2007) Conservation and Sustainability in Historic Cities, Blackwell, Oxford.

Rössler, M. (2003) 'Linking nature and culture: world heritage cultural landscapes', in M. Rössler (ed.) Cultural Landscapes: The challenges of conservation, World Heritage Papers No. 7, UNESCO World Heritage Centre, Paris.

Rössler, M. (2005) 'World heritage cultural landscapes: a global perspective', in J. Brown, N. Mitchell and M. Beresford (eds) The Protected Landscape Approach: Linking nature, culture and community, pp. 37-46, IUCN, Gland.

Russiaenhoven, F. J. W., Mijatovic, D. and Eyzaguirre, P. B. (2011) 'Social-ecological indicators of resilience in agrarian and natural landscapes', Management of Environmental Quality 22(2): 154-73.

Sarmiento, F. O. and Hitchner, S. (eds) (in press) Indigenous Revival and Sacred Sites Conservation in the Americas, Environmental Anthropology and Ethnobiology Series, Berghahn Books, New York.

Sarmiento, F. O. and X. Viteri O. (in press) 'Discursive heritage: sustaining Andean cultural landscapes amidst environmental change', in A. St Clair, K. Taylor and N. Mitchell (eds) Cultural Landscapes: Preservation challenges in the 21st century, Routledge, New York.

DD Schaaf, T. and Lee, C. (eds) (2006) Conserving Cultural and Biological Diversity: The role of sacred natural sites and cultural landscapes. International Symposium, Tokyo, UNESCO, Paris.

Sierra Nevada de Santa Marta (2014) Website. <www. sacredland.org/sierra-nevada-de-santa-marta/>

Taylor, K. and Lennon, J. (2011) 'Cultural landscapes: a bridge between culture and nature', International Journal of Heritage Studies 17: 6.

Dd Taylor, K. and Lennon, J. (eds) (2012) Managing Cultural Landscapes, Routledge, New York.
Te Heuheu, T., Kawharu, M. and Tuheiva, R. (2012) 'World heritage and indigeneity', World Heritage 62(1): 8-17.

United Nations Educational, Scientific and Cultural Organisation (UNESCO) (2001) Thematic Experts Meeting on Asia-Pacific Sacred Mountains, Final Report, UNESCO, Agency for Cultural Affairs of Japan and Wakayama Prefectural Government, Paris and Tokyo.

United Nations Educational, Scientific and Cultural Organisation (UNESCO) (2009) Hoi An Protocols for Best Conservation Practice in Asia, UNESCO, Bangkok.

United States National Park Service (NPS) (2014) Guidelines for the Treatment of Cultural Landscapes: Defining landscape terminology, US National Park Service, Washington, DC. <www.nps.gov/tps/ standards/four-treatments/landscape-guidelines/ terminology.htm>

DDd Verschuuren, B., Wild, R., McNeely, A. and Oviedo, G. (eds) (2010) Sacred Natural Sites: Conserving nature and culture, Earthscan, London.

DD Wild, R. and McLeod, C. (eds) (2008) Sacred Natural Sites: Guidelines for protected area managers, IUCN, Gland.

Williams, L. (2003) 'Keeping a sweet tradition alive', Russian Conservation News 32: 2-4. <www.wildrussia.org>

Xu, J., Ma, E. T., Tashi, D., Fu, Y., Lu, Z. and Melick, D. (2006) 'Integrating sacred knowledge for conservation: cultures and landscapes in southeast China', Ecology and Society 10(2): 7. <www. ecologyandsociety.org/vol10/iss2/art7/> 
This text taken from Protected Area Governance and Management,

edited by Graeme L. Worboys, Michael Lockwood, Ashish Kothari, Sue Feary and Ian Pulsford, published 2015 by ANU Press, The Australian National University, Canberra, Australia.

Reproduction of this ANU Press publication for educational or other non-commercial purposes is authorised without prior written permission from the copyright holder, provided the source is fully acknowledged. Reproduction of this publication for resale or other commercial purposes is prohibited without prior written permission of the copyright holder. 